\title{
A novel $D$-amino acid peptide with therapeutic potential (ISAD1) inhibits aggregation of neurotoxic disease-relevant mutant Tau and prevents Tau toxicity in vitro
}

Isabelle Aillaud ${ }^{1 \dagger}$, Senthilvelrajan Kaniyappan ${ }^{2,3+}$, Ram Reddy Chandupatla², Lisa Marie Ramirez ${ }^{4}$, Sewar Alkhashrom, Jutta Eichler ${ }^{5}$, Anselm H. C. Horn ${ }^{6,7}$, Markus Zweckstetter ${ }^{4,8}$, Eckhard Mandelkow 2,3,9, Heinrich Sticht ${ }^{6}$ and Susanne Aileen Funke ${ }^{1 *}$ (D)

\begin{abstract}
Background: Alzheimer's disease (AD), the most common form of dementia, is a progressive neurodegenerative disorder that mainly affects older adults. One of the pathological hallmarks of AD is abnormally aggregated Tau protein that forms fibrillar deposits in the brain. In AD, Tau pathology correlates strongly with clinical symptoms, cognitive dysfunction, and neuronal death.

Methods: We aimed to develop novel therapeutic D-amino acid peptides as Tau fibrillization inhibitors. It has been previously demonstrated that D-amino acid peptides are protease stable and less immunogenic than L-peptides, and these characteristics may render them suitable for in vivo applications. Using a phage display procedure against wild type full-length Tau (Tau ${ }^{\mathrm{FL}}$ ), we selected a novel Tau binding L-peptide and synthesized its D-amino acid version ISAD1 and its retro inversed form, ISAD1 rev, respectively.

Results: While ISAD1 rev inhibited Tau aggregation only moderately, ISAD1 bound to Tau in the aggregation-prone PHF6 region and inhibited fibrillization of Tau ${ }^{\mathrm{FL}}$, disease-associated mutant full-length Tau (Tau ${ }^{\mathrm{FL} \triangle K}$, Tau $^{\mathrm{FL}-\mathrm{A} 152 \mathrm{~T}}$, $\mathrm{Tau}^{\mathrm{FL}-\mathrm{P} 301 \mathrm{~L}}$ ), and pro-aggregant repeat domain Tau mutant (Tau ${ }^{\mathrm{RD} \Delta \mathrm{K}}$ ). ISAD1 and ISAD1 rev induced the formation of large high molecular weight Tau ${ }^{\mathrm{FL}}$ and Tau ${ }^{\mathrm{RD} \Delta \mathrm{K}}$ oligomers that lack proper Thioflavin-positive $\beta$-sheet conformation even at lower concentrations. In silico modeling of ISAD1 Tau interaction at the PHF6 site revealed a binding mode similar to those known for other PHF6 binding peptides. Cell culture experiments demonstrated that ISAD1 and its inverse form are taken up by N2a-Tau ${ }^{\mathrm{RD} \Delta \mathrm{K}}$ cells efficiently and prevent cytotoxicity of externally added Tau fibrils as well as of internally expressed Tau ${ }^{\mathrm{RD} \Delta K}$.
\end{abstract}

Conclusions: ISAD1 and related peptides may be suitable for therapy development of AD by promoting off-pathway assembly of Tau, thus preventing its toxicity.

Keywords: Alzheimer's disease, Tau aggregation inhibitors, Phage display, D-amino acid peptides, Therapy

*Correspondence: aileen.funke@hs-coburg.de

${ }^{\dagger}$ Isabelle Aillaud and Senthilvelrajan Kaniyappan contributed equally to this work.

${ }^{1}$ Institute of Bioanalysis, Coburg University of Applied Sciences, Coburg, Germany

Full list of author information is available at the end of the article

\section{Introduction}

Neurodegenerative diseases are often caused by protein misfolding resulting in the accumulation of protein deposits, such as amyloid fibrils [1]. Alzheimer disease (AD), the most common form of dementia, is original author(s) and the source, provide a link to the Creative Commons licence, and indicate if changes were made. The images or other third party material in this article are included in the article's Creative Commons licence, unless indicated otherwise in a credit line to the material. If material is not included in the article's Creative Commons licence and your intended use is not permitted by statutory regulation or exceeds the permitted use, you will need to obtain permission directly from the copyright holder. To view a copy of this licence, visit http://creativecommons.org/licenses/by/4.0/. The Creative Commons Public Domain Dedication waiver (http://creativeco mmons.org/publicdomain/zero/1.0/) applies to the data made available in this article, unless otherwise stated in a credit line to the data. 
characterized by two types of pathological protein deposits, extracellular amyloid plaques consisting of Amyloid- $\beta$ (A $\beta)$ peptide and intracellular neurofibrillary tangles (NFTs) consisting of Tau [2]. Tau is a microtubule (MT)binding protein that promotes and stabilizes the assembly of MTs and the regulation of axonal transport [3, 4]. Binding of Tau to MT is regulated by post-translational modifications, especially by phosphorylation [5]. Tau phosphorylation negatively regulates the binding of Tau to MT; as a result, MT stabilization and axonal transport are compromised and Tau aggregates into insoluble fibrils.

The assembly of Tau protein into paired helical filaments (PHFs) depends on two short hexapeptide sequence motifs, ${ }_{306} \mathrm{VQIVYK}_{311}$ (PHF6) and ${ }_{275} \mathrm{VQIINK}_{280}$ (PHF6*), which are located at the beginning of the third and second repeat regions, respectively [6-9]. These motifs are important for filament assembly as they form a $\beta$-sheet structure $[7,10,11]$. Accordingly, the repeat domain (RD) of Tau is sufficient for forming PHFs which are thought to contribute to AD pathology [12-17]. In addition, there is evidence that Tau-induced neuronal toxicity is predominantly caused by smaller soluble oligomeric species formed in the Tau aggregation pathway rather than large protein deposits [18-22].

In recent years, a large number of potential therapeutic substances have been developed for the prevention of $A \beta$-based pathology in $A D$, such as $A \beta$ production inhibitors, $A \beta$ aggregation inhibitors, or $A \beta$ antibodies [23-26]. Most of them failed in clinical trials due to side effects and lack of therapeutic success [27, 28]. Recently, only one $A \beta$ drug candidate (aducanumab) obtained preliminary approval from the US Food and Drug Administration (FDA), while its effectiveness will still have to be proven [29-31]. In contrast to $A \beta$ pathology, pathological changes in Tau correlate well with cognitive decline $[32,33]$. A potential approach to developing Tau-directed therapies against dementia could involve targeting the beginning of the Tau fibrilization cascade, thereby preventing the formation of toxic oligomeric species which are hypothesized to propagate from cell to cell in a prionlike manner [22,34].

A large number of Tau aggregation inhibitors have already been described as potential therapeutic agents [35-39]. In particular, D-amino acid peptides are emerging as promising drug candidates [40-42]. At least some D-peptides can be administered orally $[43,44]$ and are able to cross the blood-brain barrier in combination with high bioavailability [41, 43-48]. A promising D-peptide designated RD2, a derivate of $\mathrm{D} 3$ selected against $\mathrm{D}-\mathrm{A} \beta$ peptide using mirror image phage display, was shown to reduce plaque formation and inflammatory reactions and led to a significant improvement in the cognitive abilities of transgenic mice [43, 46-49]. The RD2 peptide has successfully completed phase 1 clinical trials. Several Tau-directed D-peptides have also been characterized in pre-clinical studies $[8,9,50,51]$. While the D-peptides TLKIVW [9] and TD28 [50] were developed to bind PHF6, MMD3 [52] was selected against the hexapeptide sequence motif PHF6*.

In the present study, we selected a peptide against the wild type full-length Tau $\left(\mathrm{Tau}^{\mathrm{FL}}\right)$ protein in order to develop potential inhibitors acting on the early stages of a pathological fibrillization cascade. First, we selected a novel L-peptide ISAL1 using a phage display selection procedure with $\mathrm{Tau}^{\mathrm{FL}}$ as a target and synthesized its D-amino acid counterpart, ISAD1, and its retro inversed version, ISAD1rev. We found that ISAD1 and its reversed form inhibit not only fibrillization of Tau ${ }^{\mathrm{FL}}$, but also of several disease-associated mutant Tau variants. Furthermore, our novel D-peptides penetrate neuronal cells and prevent cytotoxicity induced by externally added pro-aggregant repeat domain Tau mutant $\Delta \mathrm{K} 280$ $\left(\mathrm{Tau}{ }^{\mathrm{RD} \Delta \mathrm{K}}\right)$ fibril preparations as well as of internally expressed $T a u^{R D \Delta K}$. Thus, our data suggest that our novel peptide ISAD1 has an improved potential for treatment of AD, whereas ISAD1rev inhibited Tau fibrillization only moderately.

\section{Materials and methods}

\section{Tau protein expression and purification}

The gene of the human Tau ${ }^{\mathrm{FL}}$ isoform, encoding 441 amino acids (Tau 2N4R, Uniprot P10636-F), and the proaggregant mutant $\mathrm{Tau}^{\mathrm{RD} \Delta \mathrm{K}}$ were commercially synthesized and cloned into a pET28A(+) vector (Novagen, San Francisco, USA). Tau protein expression and purification was carried out according to Margittai et al. and Barghorn et al. with some modifications [53, 54]. The purity of the protein was analyzed by sodium dodecylsulfate polyacrylamide gel electrophoresis (SDS-PAGE). Protein concentrations were determined by the bicinchoninic acid (BCA) method.

\section{Preparation of Tau ${ }^{\mathrm{FL}}$ fibrils for ELISA}

The fibrillization was started by incubating $10 \mu \mathrm{M} \mathrm{Tau}^{\mathrm{FL}}$ in $20 \mathrm{mM}$ HEPES buffer, $\mathrm{pH} 6.8$ with $2.5 \mu \mathrm{M}$ heparin (16000 daltons (Da), H16K) at room temperature (RT) for $24 \mathrm{~h}$. Fibril formation was verified using the Thioflavin-T (ThT) assay. For ThT fluorescence measurements, $20 \mu \mathrm{L}$ of the sample with $10 \mu \mathrm{M}$ ThT was pipetted into a black 96-well half area clear flat-bottom plate. Tau ${ }^{\mathrm{FL}}$ without addition of heparin was used as a negative control. The fluorescence measurement was performed using a photometer POLARstar optima (BMG-Labtechnologies, Ortenberg, Germany), and excitation/emission wavelengths were set at $440 / 490 \mathrm{~nm}$. 


\section{Phage display selection}

Selection of novel peptides binding to recombinant $\mathrm{Tau}^{\mathrm{FL}}$ was performed by a phage display selection method. The target protein $\mathrm{Tau}^{\mathrm{FL}}$ was prepared in $50 \mu \mathrm{g} / \mathrm{ml}$ concentration in coating buffer $\left(0.1 \mathrm{M} \mathrm{NaHCO}_{3}, \mathrm{pH}\right.$ 8.6) and immobilized on 96-well microtiter plates (Greiner Bio-One $\mathrm{GmbH}$, Frickenhausen, Germany) overnight at $4{ }^{\circ} \mathrm{C}$. The next day, the coating solution was discarded and each well was completely filled with blocking buffer (0.1 $\mathrm{M} \mathrm{NaHCO}_{3}, \mathrm{pH} 8.6,5 \mathrm{mg} / \mathrm{ml}$ bovine serum albumin (BSA)). After blocking for $1 \mathrm{~h}$, the wells were washed 6 times with tris-buffered saline with Tween20 (TBST: TBS $+0.1 \%[\mathrm{v} / \mathrm{v}]$ Tween-20). One hundred microliters of a 100-fold dilution of the phage library, displaying 12-mer random peptides (Ph.D.-12, New England Biolabs, Frankfurt a.M., Germany), was incubated for 1 $\mathrm{h}$ with agitation. To remove unbound phages, the wells were again washed 10 times with TBST. Bound phages were then eluted using $0.2 \mathrm{M}$ Glycine- $\mathrm{HCl}(\mathrm{pH} 2.2)$ with $1 \mathrm{mg} / \mathrm{ml}$ BSA. The phages were then amplified according to the manufacturer's instructions (New England Biolabs, Frankfurt a.M., Germany) and used for the following 3 panning rounds.

\section{Single phage clone ELISA}

A single clone binding assay was performed by enzymelinked immunosorbent assay (ELISA) with the supernatant of amplified phage clones from selection round three and four to identify the single phages showing the strongest binding to $\mathrm{Tau}^{\mathrm{FL}}$. Therefore, Tau ${ }^{\mathrm{FL}}(50 \mu \mathrm{g} / \mathrm{ml})$ diluted in coating buffer was immobilized on polystyrene 96-well microtiter plates (Greiner Bio-One $\mathrm{GmbH}$, Frickenhausen, Germany) overnight at $4{ }^{\circ} \mathrm{C}$. The control wells contained only buffer without target protein. The next day, the coating solution was discarded and incubated with $100 \mu$ of blocking buffer (1\% BSA in $50 \mathrm{mM}$ Tris, $150 \mathrm{mM} \mathrm{NaCl}, \mathrm{pH}$ 7.6) for $1 \mathrm{~h}$. To avoid the selection of possible BSA-binding phages, the supernatant of third and fourth selection round was mixed with blocking buffer in a ratio of 1:1 and pre-incubated for $20 \mathrm{~min}$ at RT with gentle agitation. After blocking, the plate was washed 6 times with TBST and $100 \mu \mathrm{l}$ of the pre-incubated diluted samples was transferred into the appropriate wells. Subsequently, the plates were incubated for 1 $\mathrm{h}$ at RT with gentle agitation, followed by a washing step with TBST (6 times with $100 \mu \mathrm{l}$ ). Afterwards, $150 \mu \mathrm{l}$ of the anti-M13 antibody dilution horseradish peroxidase (HRP)/anti-M13 (Monoclonal Conjugate; GE-Healthcare, Freiburg, Germany) was added to the adequate wells for $1 \mathrm{~h}$ at RT, followed by 6 times washing with TBST. The anti-M13 antibody was diluted 1:5000 in blocking buffer. Detection was conducted by measuring the conversion of the substrate tetramethylbenzidine (TMB) by HRP. One hundred microliters of the substrate solution was transferred to the respective sample wells. The enzyme reaction was stopped by adding $100 \mu \mathrm{l}$ of $20 \%[\mathrm{v} / \mathrm{v}] \mathrm{H}_{2} \mathrm{SO}_{4}$. The absorption of the reaction product was measured at $450 \mathrm{~nm}$ in a Multiscan Go (Thermo Fisher Scientific, Darmstadt, Germany) microplate reader.

Positive phages from ELISA were selected for DNA isolation. DNA sequencing was performed at LGC Genomics (Berlin, Germany). The DNA sequences were translated into 12-mer amino acids, aligned using CLUSTAL Omega program (http://www.ebi.ac.uk/Tools/ $\mathrm{msa} / \mathrm{clustalo} /$ ), and analyzed using the SAROTUP Database (an abbreviation of "Scanner And Reporter Of Target-Unrelated Peptides") [55].

\section{Peptides}

The selected peptide sequences obtained from the phage display selection were first synthesized as L-amino acid peptides. ISAL1 to 4 and ISAL9 (Table 1 ) were purchased from JPT Peptide Technologies (Berlin, Germany). L-peptides ISAL5 to ISAL8 and ISAL1sam were synthesized in the lab of Prof. Eichler as described in the supplement. Later, unlabeled and fluorescein amidites (FAM)-labeled peptides ISAD1 and ISAD1rev (all amino acids of both peptides are D-enantiomers) with > 95\% purity were purchased from JPT Peptide Technologies as well. The FAM label is attached to the $\mathrm{C}$-terminus of the peptides with an additional lysine residue in between. PHF6 and PHF6* were purchased as N-terminally acetylated hexapeptides to allow self-aggregation.

Table 1 Selected L-peptides from phage display selection against $\mathrm{Tau}^{\mathrm{FL}}$

\begin{tabular}{lllll}
\hline Nr. & Sequence & Frequency & $\begin{array}{l}\text { Inhibition } \\
\text { of Tau } \\
\text { aggregation }\end{array}$ & Name \\
\hline 1 & SVFKLSLTDAAS & $1 / 80$ & + & ISAL1 \\
2 & NHDMDLLVWWMN & $1 / 80$ & $+/-$ & ISAL2 \\
3 & NWSMPGMTQGFL & $13 / 80$ & - & ISAL3 \\
4 & DFHQRDDDSQQA & $1 / 80$ & - & ISAL4 \\
5 & AMYQFSRNPHLP & $3 / 80$ & - & ISAL5 \\
6 & VSPAWDARTRSA & $2 / 80$ & - & ISAL6 \\
7 & MTPHGNSKTPSG & $1 / 80$ & - & ISAL7 \\
8 & HDWYRSPRMGLF & $1 / 80$ & - & ISAL8 \\
9 & DLSHGQDLMHHH & $1 / 80$ & - & ISAL9 \\
10 & SASVTSKFDALL & - & - & ISAL1sam \\
\hline
\end{tabular}

The peptide sequences were determined after DNA sequencing of the positive phages. Each sequence was given a number in the list. (+/-) indicates comparably low inhibition of Tau ${ }^{\mathrm{FL}}$ fibrillization, (-) indicates that the peptide showed no effect on fibril formation. The scrambled peptide (ISAL1sam) was synthesized and did not show any inhibition of $\mathrm{Tau}^{\mathrm{FL}}$ fibrillization 


\section{Detection of peptide binding to Tau conformers using ELISA}

A 96-well microtiter plate (Greiner Bio-One GmbH, Frickenhausen, Germany) was coated with $5 \mu \mathrm{g} / \mathrm{ml} \mathrm{Tau}^{\mathrm{FL}}$ or fibrils in coating buffer for incubation overnight at $4{ }^{\circ} \mathrm{C}$. For investigation of the binding properties to the hexapeptide, $5 \mu \mathrm{M}$ PHF6 was coated overnight. After three times washing with $300 \mu \mathrm{l}$ phosphate-buffered saline with Tween20 (PBST: PBS with $0.1 \%$ [v/v] Tween20), the plate was blocked with $3 \%[\mathrm{w} / \mathrm{v}]$ BSA in PBS for $1 \mathrm{~h}$ at RT, followed by further washing steps. Subsequently, 100 $\mu \mathrm{l}$ FAM-labeled peptides was added at a final concentration of 0.1 to $20 \mu \mathrm{g} / \mathrm{ml}$ in PBST and incubated for $1 \mathrm{~h}$ at RT. The plate was washed three times with PBST before $100 \mu \mathrm{l}$ sheep anti-fluorescein isothiocyanate (FITC) HRPconjugate (1:5000 dilution in PBST; AbD Serotec, Puchheim, Germany) was added and incubated for $1 \mathrm{~h}$ at RT with gentle agitation. Again, the plate was washed for three times, followed by addition of the TMB substrate. The reaction was stopped with $20 \%[\mathrm{v} / \mathrm{v}] \mathrm{H}_{2} \mathrm{SO}_{4}$ and absorbance was measured at $450 \mathrm{~nm}$.

\section{In silico modeling of binding mode of ISAD1 to PHF6 fibrils} Modeling of the ISAD1 peptide complex with PHF6 was guided by previous models of PHF6 with D-peptides TLKIVW [9] and TD28 [50]. ISAD1 was modeled in the same extended geometry and the same binding register as the TLKIVW and TD28 D-peptides. The binding register was chosen according to the position of a conserved $\Phi+\Phi$ ( $\Phi$ hydrophobic residue; + central positively charged residue) sequence motif present in all these PHF6-binding peptides. Modeling was performed with Sybyl 7.3 (Tripos Inc., St. Louis, USA) and UCSF Chimera [56]. Structural analysis of the complexes between the PHF6 oligomers and the docked peptides was performed with VMD [57].

\section{Fibrillization of Tau ${ }^{\mathrm{FL}}$ monitored by ThT assay}

Tau aggregation assays were performed under reducing conditions. Before the addition of heparin and peptides, a final concentration of $1 \mathrm{mM}$ dithiothreitol (DTT) was added to the Tau protein solution and heated at $95{ }^{\circ} \mathrm{C}$ for $10 \mathrm{~min}$. For Tau ${ }^{\mathrm{FL}}$ inhibition assays, $5 \mu \mathrm{M}$ Tau ${ }^{\mathrm{FL}}$ were incubated in HEPES buffer ( $\mathrm{pH}$ 6.7) in the presence of $1.25 \mu \mathrm{M}$ heparin at $37^{\circ} \mathrm{C}$ for $48 \mathrm{~h}$ with or without novel D-peptides (ISAD1 and ISAD1rev) at different concentrations ( $1 \mathrm{nM}$ to $200 \mu \mathrm{M})$. Final concentration of $10 \mu \mathrm{M}$ ThT was used for monitoring fibrillization. In case of the two hexapeptides, $5 \mu \mathrm{M}$ PHF6 and $5 \mu \mathrm{M}$ PHF6*, respectively, without addition of the aggregation inducer heparin (16000 Da) were used for monitoring the fibrillization process. The assays were performed with $50-\mu$ l sample volume per well in a 96-well half area microtiter plate
(Greiner Bio-One GmbH, Frickenhausen, Germany). The fibrillization of $\mathrm{Tau}^{\mathrm{FL}}$ was monitored by ThT, and the relative fluorescence intensity of ThT was read out at 440 excitation/521 emission $\mathrm{nm}$ in a BMG microplate reader (BMG Labtech, Ortenberg, Germany).

\section{Fibrillization of Tau ${ }^{\mathrm{RD} \Delta \mathrm{K}}$ and Tau mutants monitored by Thioflavin-S (ThS) assay}

For Tau fibrillization inhibition assays, $10 \mu \mathrm{M}$ Tau mutant protein $\left(\mathrm{Tau}^{\mathrm{RD} \Delta \mathrm{K}}, \mathrm{Tau}^{\mathrm{FL} \Delta \mathrm{K}}, \mathrm{Tau}^{\mathrm{FL}-\mathrm{A} 152 \mathrm{~T}}, \mathrm{Tau}^{\mathrm{FL}-\mathrm{P} 301 \mathrm{~L}}\right)$ was incubated in BES buffer (N,N-bis(2-hydroxyethyl)-2-aminoethanesulfonic acid, $\mathrm{pH} 7$ ) in the presence of $2.5 \mu \mathrm{M}$ heparin at $37{ }^{\circ} \mathrm{C}$ for $24 \mathrm{~h}$ with and without novel D-peptides (ISAD1 and ISAD1rev) at different concentrations $(1 \mathrm{nM}$ to $200 \mu \mathrm{M})$. Final concentration of $20 \mu \mathrm{M}$ ThS was used for monitoring fibrillization. The assay was performed with $40-\mu \mathrm{l}$ sample volume per well in a 384-well microtiter plate (Thermo LabSystems, Dreieich, Germany). The fibrillization of Tau was monitored by ThS and the relative fluorescence intensity of ThS was read out at 440 excitation/521 emission $\mathrm{nm}$ in a Tecan micro titer plate reader (Tecan, Männedorf, Switzerland).

\section{Dynamic light scattering (DLS)}

After the ThS assay (end time point, $24 \mathrm{~h}$ ), the samples were used for DLS measurements. Twenty microliters of the sample was placed in a quartz batch cuvette (ZEN2112) and the measurement was performed at 25 ${ }^{\circ} \mathrm{C}$ in a Zetasizer Nano $\mathrm{S}$ instrument (Malvern Instruments, Herrenberg, Germany). The sample was thermally equilibrated at $25{ }^{\circ} \mathrm{C}$ for $2 \mathrm{~min}$. The mean value of the intensities of an individual sample was determined over 3 measurements with 15 runs each. Analysis and averaging of the collected data were performed with the Zetasizer software 7.11 (Malvern Instruments, Herrenberg, Germany) and the result is represented as a volume graph. $\mathrm{Tau}^{\mathrm{RD} \Delta \mathrm{K}}$ fibrils (Tau+heparin) formed in the absence of D-peptides was used as a positive control.

\section{Pelleting assay and western blot}

After the ThS assay (end time point, $24 \mathrm{~h}$ ), $70 \mu \mathrm{l}$ of each sample (pooled together from 2 wells) was centrifuged in a Beckmann coulter (Optima Max Ultra Centrifuge, TLA 100.3 rotor) at $61,000 \mathrm{rpm}$ for $60 \mathrm{~min}$ at $4{ }^{\circ} \mathrm{C}$. After centrifugation, the supernatant was separated from the pellet. Then, the pellet was dissolved in BES buffer in an equal volume as the supernatant. For the following western blot, $12-\mu \mathrm{l}$ samples were mixed with $3-\mu \mathrm{l}$ SDS-sample buffer (5x), heated for $5 \mathrm{~min}$ at $95{ }^{\circ} \mathrm{C}$, and loaded onto a 8-16\% SDS tris-glycine-gel (BioRad, Feldkirchen, Germany). The proteins were transferred to a polyvinylidene fluoride (PVDF) membrane. After the transfer, the membrane was blocked in 5\% non-fat dry milk. After washing 
the membrane three times for $10 \mathrm{~min}$ with TBST, the primary pan-Tau K9JA antibody (1:5000; Agilent, Waldbronn, Germany) was incubated for $1 \mathrm{~h}$ at RT with gentle agitation, followed by again 3-times washing with TBST. For detection on western blot, the secondary antibody (goat anti-rabbit HRP, Agilent, Waldbronn, Germany) was incubated in a 1:2000 dilution for $1 \mathrm{~h}$ at RT with shaking. After another washing step (3 times with TBST), imaging was done with chemiluminescence substrate (Amersham $^{\mathrm{TM}}$, ECL Prime Western Blotting Detection Reagents, GE Healthcare, Chicago, USA) and Image Quant ${ }^{\text {TM }}$ LAS 4000 (GE Healthcare, Chicago, USA). The quantification of intensities was performed using ImageJ.

\section{Cell culture}

Cells of a Neuro-2a (N2a) Tau ${ }^{\mathrm{RD} \Delta \mathrm{K}}$ inducible cell line $\left(\mathrm{N} 2 \mathrm{a}-\mathrm{Tau}{ }^{\mathrm{RD} \Delta \mathrm{K}}\right)$ [58] were grown in minimal essential media (MEM, Sigma Aldrich, Darmstadt, Germany) supplemented with $10 \%$ fetal bovine serum (FBS), $5 \mathrm{ml}$ non-essential amino acids (PAA, Pasching, Austria), and $1 \mathrm{X}$ penicillin and streptomycin antibiotics at 37 ${ }^{\circ} \mathrm{C}$ with $5 \% \mathrm{CO}_{2}$. The inducible $\mathrm{N} 2 \mathrm{a}$ cell line expressing $\mathrm{Tau}^{\mathrm{RD} \Delta \mathrm{K}}$ require antibiotics geneticin G418 $(300 \mu \mathrm{g} /$ $\mathrm{ml})$ and hygromycin $(100 \mu \mathrm{g} / \mathrm{ml})$. Tau ${ }^{\mathrm{RD} \Delta \mathrm{K}}$ expression was induced by incubating cells with $1 \mu \mathrm{g} / \mathrm{ml}$ doxycycline (Dox) in the studies on the detoxification of cellular $\mathrm{Tau}^{\mathrm{RD} \Delta \mathrm{K}}$ by the D-peptides; otherwise, these cells did not express the $\mathrm{Tau}^{\mathrm{RD} \Delta \mathrm{K}}$ protein.

\section{Cell viability assays}

Cell viability was analyzed in accordance with the manufacturer's protocol (Roche Diagnostics, Mannheim, Germany; cell proliferation kit II (MTT)). This assay is based on the cleavage of the yellow tetrazolium salt MTT into purple formazan dye by metabolic active cells. The color changes only in viable cells and can be directly quantified using a scanning multiwell spectrophotometer. In all experiments, the cells were grown as described previously. The cells $(25,000$ cells/well or $80 \%$ confluence) were plated on poly D-lysine-coated 96-well plates (Greiner Bio-One GmbH, Frickenhausen, Germany) for stronger attachment from overnight to $24 \mathrm{~h}$ at $37{ }^{\circ} \mathrm{C}$. Fibrillized $\mathrm{Tau}^{\mathrm{RD} \Delta \mathrm{K}}$ was generated by incubating $200 \mu \mathrm{M}$ $\mathrm{Tau}^{\mathrm{RD} \Delta \mathrm{K}}$ in BES buffer at $37^{\circ} \mathrm{C}$ for $24 \mathrm{~h}$ in the presence of $2 \mathrm{mM}$ D-peptides $\left(\mathrm{Tau}^{\mathrm{RD} \Delta \mathrm{K}}\right.$ :peptide $\left.=1: 10\right)$. Successful fibrillization was verified using ThS $\left(5 \mu \mathrm{M}\right.$ Tau ${ }^{\mathrm{RD}} \Delta \mathrm{K}$, $10 \mu \mathrm{M} T h S)$ measurement. The aggregated Tau ${ }^{\mathrm{RD} \Delta \mathrm{K}}(10$ $\mu \mathrm{M}$ final concentration), $\mathrm{Tau}^{\mathrm{RD} \Delta \mathrm{K}}(10 \mu \mathrm{M})+$ peptide (100 $\mu \mathrm{M})$ samples (ISAD1 and ISAD1rev), buffer only (negative control, set to $100 \%$ cell viability), and TritonX-100 ( $2 \%$, cytotoxic agent, positive control) were incubated on $\mathrm{N} 2 \mathrm{a}-\mathrm{Tau}^{\mathrm{RD} \Delta \mathrm{K}}$ cells $(100 \mu \mathrm{l}$ solution) for another $24 \mathrm{~h}$. The cell viability was measured in accordance with the manufacturer's protocol.

\section{Measurement of lactate dehydrogenase (LDH) release} N2a cells expressing $\mathrm{Tau}^{\mathrm{RD} \Delta \mathrm{K}}$ were plated on poly D-lysine-coated 96-well plates with a density of 25,000 cells/well. At 70 to $80 \%$ confluence, the cells were treated for $24 \mathrm{~h}$ with various concentrations of D-peptides $(25$, $50,100$, and $250 \mu \mathrm{M})$ or Tau ${ }^{\mathrm{RD} \Delta \mathrm{K}}(10 \mu \mathrm{M}$ final concentration) in the presence of ISAD1 and ISAD1rev $(100 \mu \mathrm{M}$ final concentration). The ability of D-peptides to neutralize the toxicity of $\mathrm{Tau}^{\mathrm{RD} \Delta \mathrm{K}}$ oligomers/fibrils was investigated by measuring the amount of released LDH (Roche Diagnostics, Mannheim, Germany). Therefore, $50 \mu \mathrm{L}$ of each well was transferred to a fresh 96-well plate and 50 $\mu \mathrm{L}$ of reagent was added followed by a 30-min incubation period at RT. Finally, $50 \mu \mathrm{L}$ of stop solution $(1 \mathrm{~N} \mathrm{HCl})$ was added and absorbance was recorded at $492 \mathrm{~nm}$ (TECAN spectrofluorometer, Männedorf, Switzerland). Absorbance values were corrected by background values and the percentage of LDH release was calculated.

\section{Reactive oxygen species (ROS) measurements}

Toxic Tau oligomers and fibrils can induce the production of superoxides and peroxy radicals in cells which can be measured with fluorescent dye dichlorodihydrofluorescein (DCF). N2a-Tau ${ }^{\mathrm{RD} \Delta \mathrm{K}}$ cells were plated on D-lysine-coated 96-well plates. At 70 to $80 \%$ confluence, the cells were washed once with warm PBS and then incubated with $20 \mu \mathrm{M}$ of DCF (Abcam, Cambridge, UK) diluted in $1 \mathrm{X}$ dilution buffer for $30 \mathrm{~min}$ at $37^{\circ} \mathrm{C}$. After $30 \mathrm{~min}$, the cells were washed once with $1 \mathrm{X}$ PBS. After washing, the cells were incubated with desired concentrations of different samples $(10 \mu \mathrm{M}$ oligomers/fibrils \pm treated with $100 \mu \mathrm{M}$ D-peptides or controls) for $30 \mathrm{~min}$. The cytotoxic agent TBHP (tert-butylhydroperoxide) was used as the positive control. The fluorescence intensity was measured using a spectrofluorometer (Tecan, Männedorf, Switzerland; excitation at $485 \mathrm{~nm}$ and emission at $535 \mathrm{~nm}$ ).

\section{Effect of ISAD1 and ISAD1 rev on cellular Tau ${ }^{\mathrm{RD} \Delta K}$ aggregation}

After the N2a-Tau ${ }^{\mathrm{RD} \Delta \mathrm{K}}$ cells reached the desired confluence $(25,000$ cells/well or $80 \%)$, intracellular Tau ${ }^{R D \Delta K}$ expression was induced by the addition of $1 \mu \mathrm{g} / \mathrm{ml}$ Dox. The cells were plated on poly D-lysine-coated 96-well plates (Greiner Bio-One $\mathrm{GmbH}$, Frickenhausen, Germany) and treated with ISAD1 and ISAD1rev in a concentration range of 25 to $250 \mu \mathrm{M}$. TritonX-100 (2\%) was used as a positive control. The incubation and Tau ${ }^{\mathrm{RD} \Delta \mathrm{K}}$ expression time was $72 \mathrm{~h}$. Following incubation, cell 
viability was studied by measuring MTT and LDH release in accordance with the manufacturer's protocol.

\section{Results}

\section{Phage display selection against Tau ${ }^{\mathrm{FL}}$}

Selection of peptides against recombinant $\mathrm{Tau}^{\mathrm{FL}}$ was performed using a commercial peptide library of phages encoding $>1 \times 10^{9}$ different random 12-amino acid sequences. Briefly, $\mathrm{Tau}^{\mathrm{FL}}$ was immobilized on microtiter plates for the selection procedure. In case of the 441 amino acid $\mathrm{Tau}^{\mathrm{FL}}$, a direct mirror image phage display selection to generate $\mathrm{D}$-amino acid peptides was not practicable, as synthesis of $\mathrm{Tau}^{\mathrm{FL}}$ consisting of $\mathrm{D}$-amino acids was not possible. After four rounds of biopanning, single phages of the finally enriched phage dilution were tested for their ability to bind $\mathrm{Tau}^{\mathrm{FL}}$ using single phage ELISA. The peptide sequences of promising phages, which showed relatively high signal in comparison to the negative control, were determined by DNA sequence analysis of the respective genome region. We found one single dominating amino acid sequence (consensus sequence) in 80 phages and some sequences were selected twice or three times (Table 1). All L-peptide sequences found after selection were compared to already known peptide sequences listed in the SAROTUP database ("Scanner And Reporter Of Target-Unrelated Peptides") [55] to exclude possible target-unrelated peptides (TUPs) from biopanning results. Nine L-peptides were chosen for further characterization and for testing their potential to inhibit Tau ${ }^{\mathrm{FL}}$ aggregation using the ThT fibrillization assay (Table 1). To our surprise, the L-peptides that carried the consensus sequence (ISAL3) did not inhibit $\mathrm{Tau}^{\mathrm{FL}}$ aggregation. Instead, ISAL1 induced the highest reduction of Tau ${ }^{\mathrm{FL}}$ fibrillization in the ThT assays.

Furthermore, to test whether ISAL1 inhibited Tau ${ }^{\mathrm{FL}}$ fibrillization in a sequence-specific way, we performed additional ThT studies with a scrambled L-amino acid variant of ISAL1 (ISAL1sam), in which the amino acid sequence was randomly mixed. The scrambled control peptide did not inhibit the Tau ${ }^{\mathrm{FL}}$ fibrillization (Sup. Fig. 1A) and showed no significant binding to $\mathrm{Tau}^{\mathrm{FL}}$ (Sup. Fig. 1B) in ELISA.

As we intended to obtain Tau-binding-D-peptides for a later possible in vivo application, ISAL1 was synthesized as a D-peptide (ISAD1) and its retro inversed form (ISAD1rev) for further characterization.

\section{ISAD1 and ISAD1 rev bind to both non-fibrillized Tau ${ }^{\mathrm{FL}}$ and Tau ${ }^{\mathrm{FL}}$ filaments}

ELISA analysis demonstrated that ISAD1 and ISAD1rev bind to non-fibrillized $\mathrm{Tau}^{\mathrm{FL}}$ and filaments of $\mathrm{Tau}^{\mathrm{FL}}$ with similar strength (Fig. 1A). The half maximal effective

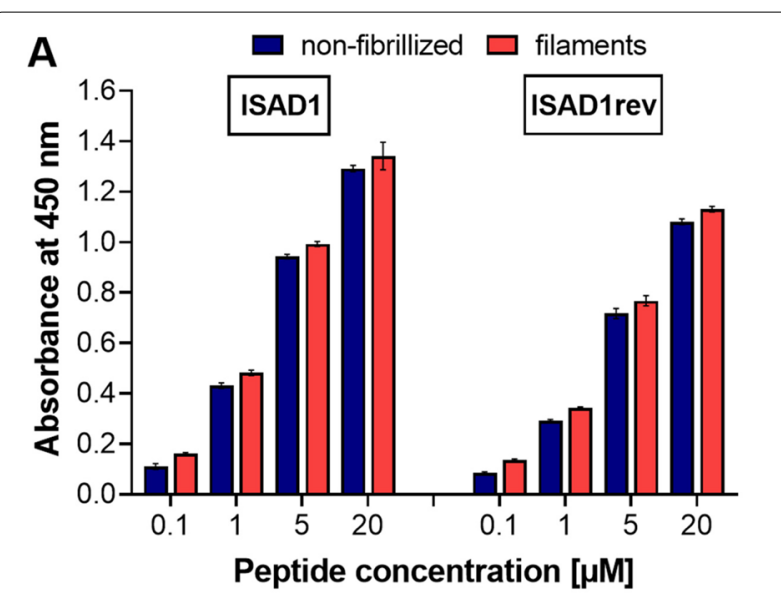

B

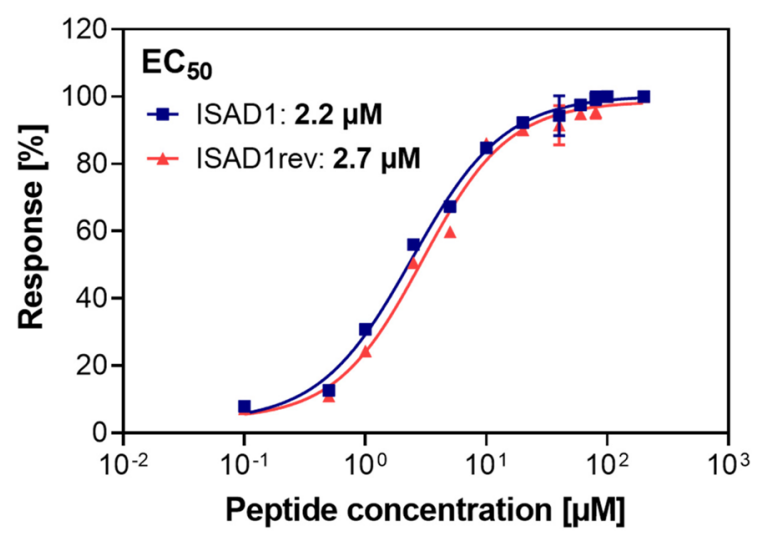

Fig. 1 Binding properties of ISAD1 and ISAD1 rev to non-fibrillized Tau ${ }^{\mathrm{FL}}$ and $\mathrm{Tau}^{\mathrm{FL}}$ filaments. A The plates coated with $5 \mu \mathrm{g} / \mathrm{ml}$ of Tau ${ }^{\mathrm{FL}}$ and Tau ${ }^{\mathrm{FL}}$ filaments were incubated with different concentrations of FAM-labeled peptides (ISAD1 and ISAD1 rev) and the binding of the peptides was analyzed by ELISA. B Dose-response curve of Tau ${ }^{\mathrm{FL}}$ with FAM-labeled peptides ISAD1 and ISAD1 rev (0.1-200 $\mu$ M) analyzed by ELISA. The EC $C_{50}$ was calculated for ISAD1 at $2.2 \mu \mathrm{M}$ and ISAD1 rev $2.7 \mu \mathrm{M}$, by non-linear regression

PHF6:

Sievers:

TD28:

APT:

ISAD1:

Sequence Motif:

Fig. 2 ISAD1 shows a similar binding motif to previously described PHF6 binding peptides. Sequence comparison of the ISAD1 peptide to PHF6 and other PHF6-binding peptides from the previous studies of Sievers et al. [9] and Dammers et al. [50]. The peptides are aligned according to the presence of a conserved basic (+) residue (shown in blue) which interacts with Q307 of PHF6 (shown in bold green). In all the peptides, this basic residue is flanked by two hydrophobic ( $\Phi$ ) residues (shown in bold) resulting in a $\Phi+\Phi$ motif. In some peptides, an additional hydrophobic residue is present spaced by a variable ( $x$ ) residue resulting in a $\Phi+\Phi \times \Phi$ motif (shown in bold) 
concentrations $\left(\mathrm{EC}_{50}\right)$ values of the peptides ISAD1 (2.2 $\mu \mathrm{M})$ and ISAD1rev (2.7 $\mu \mathrm{M})$ were calculated (Fig. 1B).

Furthermore, we investigated the interactions between ISAD1 and Tau ${ }^{\mathrm{FL}}$ monomers by NMR which revealed only weak binding (Sup. Fig. 2A and 2B), similar to other previously identified peptides $[9,52]$. However, binding of ISAD1 to unfibrilized $\mathrm{Tau}^{\mathrm{FL}}$ was revealed by ELISA studies (Fig. 1A).

\section{In silico analysis of binding mode}

Using ELISA, the peptide PHF6 emerged as one possible binding site of ISAD1 (Sup. Fig. 3A). Subsequently,

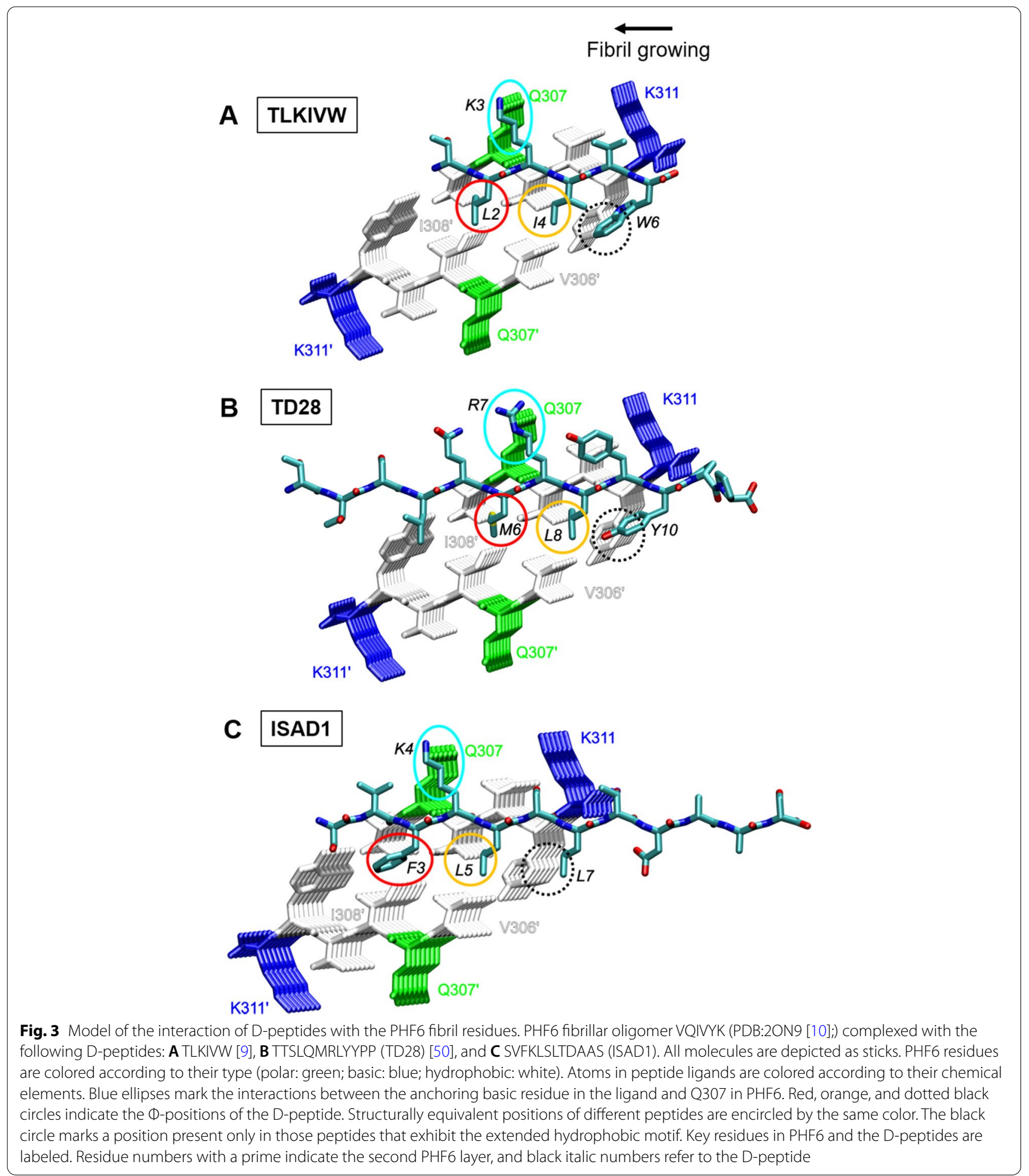


we compared the sequence of ISAD1 to several other D-peptides that were previously reported to bind to the PHF6 site of Tau (Fig. 2). As a common sequence motif, all these peptides exhibit a basic residue (Fig. 2: blue bold letter) flanked by two hydrophobic residues (Fig. 2; two bold black letters) resulting in a $\Phi+\Phi$ motif. In some of the peptides (for example: ISAD1; TD28), an additional hydrophobic residue is present spaced by a variable residue resulting in a $\Phi+\Phi \times \Phi$ motif (Fig. 2; all bold black letters). Notably, this sequence motif is absent in the PHF6"-binding peptides MMD3 and MMD3rev reported in Malhis et al. [52].

The presence of a common sequence motif in the PHF6-binding D-peptides (Fig. 2) prompted us to model ISAD1 in the same binding mode as TLKIVW [9] and TD28 [50] to investigate the PHF6-peptide interactions. Figure 3 shows the similarity between the four D-peptide complexes with PHF6. Similar to TLKIVW and TD28 and ISAD1 can establish favorable side chain contacts between the central positively charged residue ( $R$ in TD28; $\mathrm{K}$ in TLKIVW and ISAD1) and Q307 of PHF6 (Fig. 3: blue circle), which presents an anchor for the $\beta$-sheet register. Additional stabilizing interactions arise from the hydrophobic residues flanking the central basic residue (Fig. 3: red and yellow circles). Furthermore, the three D-peptides TLKIVW, TD28, and ISAD1 possess a third hydrophobic residue corresponding to the C-terminal position of the $\Phi+\Phi \times \Phi$ motif that forms interactions to the steric zipper near the edge of the fibril (Fig. 3: black dotted circle). Here, we found that ISAD1 has a similar sequence motif and binding mode as previously described peptides.

\section{ISAD1 and ISAD1 rev inhibit the fibrillization of Tau ${ }^{\mathrm{FL}}$ and Tau ${ }^{\mathrm{RD} \Delta K}$}

Initially, ISAD1 and ISAD1rev were tested for their potential to inhibit the heparin-induced fibrillization of $\mathrm{Tau}^{\mathrm{FL}}$ and $\mathrm{Tau}{ }^{\mathrm{RD} \Delta \mathrm{K}}$ using in vitro fibrillization assay monitored by ThT or ThS (Fig. 4). The formation of Tau ${ }^{\mathrm{FL}}$ fibrils was monitored by ThT in the presence of different concentrations $(1 \mathrm{nM}-200 \mu \mathrm{M})$ of respective peptides. Fibrillization of $\mathrm{Tau}^{\mathrm{FL}}$ was significantly reduced above $1 \mu \mathrm{M}$ of peptide concentration (Fig. 4A). Based on the
$\mathrm{IC}_{50}$ value, the ISAD1 peptide $(2.91 \mu \mathrm{M})$ has a $\sim 7$ times higher efficiency in inhibiting fibrillization of $\mathrm{Tau}^{\mathrm{FL}}$ than ISAD1rev (20.96 $\mu \mathrm{M})$ (Fig. 4B).

Since the $\mathrm{Tau}^{\mathrm{RD}}$ generally aggregates more efficiently than full-length Tau (where the other domains partially shield the repeat domain), we then tested the effects of the D-peptides on mutant $\operatorname{Tau}^{\mathrm{RD} \Delta \mathrm{K}}$ [6]. This again showed that ISAD1 is a much more potent aggregation inhibitor $\left(\mathrm{IC}_{50}-2.9 \mu \mathrm{M}\right)$ than its inversed version $\left(\mathrm{IC}_{50}-\right.$ $17.8 \mu \mathrm{M}$ ) (Fig. 4C, D).

After identifying PHF6 as a binding site of ISAD1, we investigated the effect of ISAD1 on the fibrillization of PHF6 and PHF6* (Sup. Fig. 3B). At $25 \mu \mathrm{M}$ concentration, ISAD1 inhibited fibril formation of PHF6, but not of PHF6*. None of the peptides showed self-fibrillization tendencies without Tau under assay procedure conditions (data not shown).

\section{ISAD1 and ISAD1 rev inhibit the fibrillization of neurotoxic mutant Tau}

Next, we studied the effects of D-peptides in inhibiting the aggregation of physiologically relevant full-length Tau carrying disease-causing mutations such as $\Delta \mathrm{K} 280$ (in R2 of RD), A152T (in proline-rich domain), and P301L (in $\mathrm{R} 2$ of RD) which are found in frontotemporal dementia with parkinsonism linked to chromosome 17 (FTDP-17), progressive supra-nuclear palsy (PSP), and AD patients. These mutations have only a mild effect on Tau-induced MT assembly but modulate the propensity for aggregation, which corresponds to toxic effects in transgenic mice [59-61]. In particular, mutations $\Delta \mathrm{K} 280$ and P301S increase the propensity for $\beta$-structure of the repeat domain and thus strongly enhance fibrillization [17, 62], whereas mutation A152T (in the proline-rich domain P1) promotes oligomerization [63]. Therefore, we studied the ability of D-peptides to inhibit the fibrillization of three different Tau mutant forms $\left(\mathrm{Tau}^{\mathrm{FL} \Delta \mathrm{K}}\right.$, Tau ${ }^{\mathrm{FL}-\mathrm{A} 152 \mathrm{~T}}$, $\left.\mathrm{Tau}^{\mathrm{FL}-\mathrm{P} 301 \mathrm{~L}}\right)$. ISAD1 inhibited the fibrillization of all these Tau mutants in a concentration-dependent manner (Tau:peptide $=1: 1 ; 1: 5 ; 1: 10$ ). At $10-\mu \mathrm{M}$ concentration of D-peptide, ISAD1 already inhibited the fibrillization of A152T mutant Tau by $80 \%$ (Fig. 5B), and at $50 \mu \mathrm{M}$ or more, we observed a complete inhibition (> 90\%) of

(See figure on next page.)

Fig. 4 ISAD1 and ISAD1 rev inhibit the aggregation of Tau ${ }^{\mathrm{FL}}$ and Tau ${ }^{\mathrm{RD}} \Delta \mathrm{K}$. A Fibrillization curves of Tau ${ }^{\mathrm{FL}}$ in the presence of different concentrations of the peptide ISAD1 over a period of $24 \mathrm{~h}$. The assay was performed using $5 \mu \mathrm{M}$ Tau ${ }^{\mathrm{FL}}$ with $1.25 \mu \mathrm{M}$ heparin (H16K) and $10 \mu \mathrm{M}$ ThT in HEPES buffer. ISAD1 was added in concentrations of $0.1 \mathrm{nM}$ to $200 \mu \mathrm{M}$. B Dose-response curve of Tau ${ }^{\mathrm{FL}}$ fibrillization process in the presence of ISAD1 and ISAD1 rev $(0.1 \mathrm{nM}-200 \mu \mathrm{M})$. C $10 \mu \mathrm{M}$ Tau ${ }^{\mathrm{RD} \Delta \mathrm{K}}$ in BES buffer was incubated with $2.5 \mu \mathrm{M}$ heparin and $20 \mu \mathrm{M}$ ThS to monitor fibrillization. D Dose-response curve of Tau ${ }^{\mathrm{RD} \Delta \mathrm{K}}$ in the presence of ISAD1 and ISAD1 rev. The relative fluorescence of a buffer sample was subtracted. Fluorescence was measured at $520 \mathrm{~nm}$ in relative units (mean \pm standard deviations of results, three replicates per run). The fluorescence of Tau ${ }^{\mathrm{FL}}$, Tau ${ }^{\mathrm{RD} \Delta \mathrm{K}} \mathrm{was}_{\mathrm{set}}$ as $100 \%$ and the values and standard deviations of the other incubations are given as percentages of this maximum value. The data represent the mean values \pm SD with $n=3$ determinations 
A

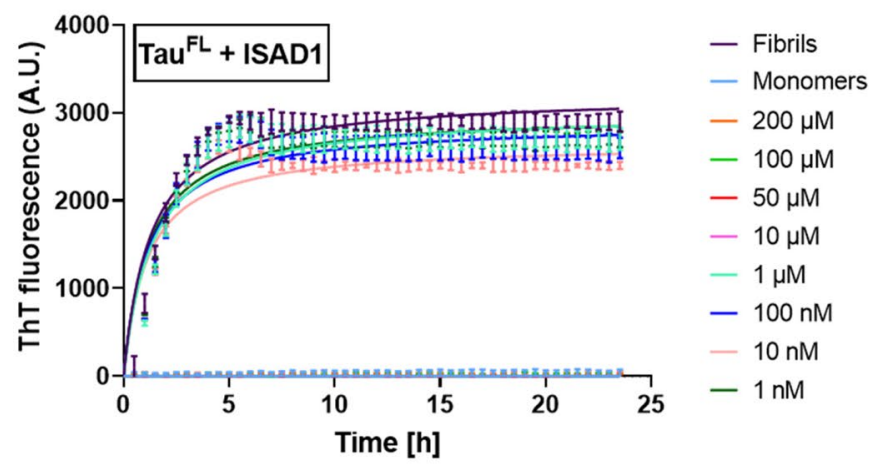

B

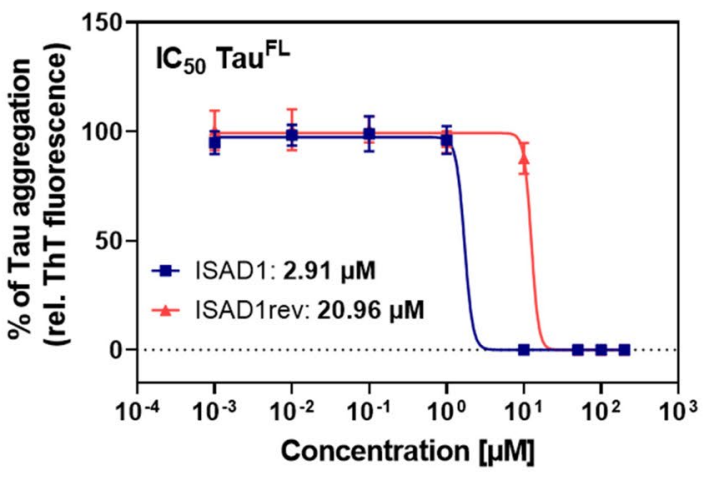

C

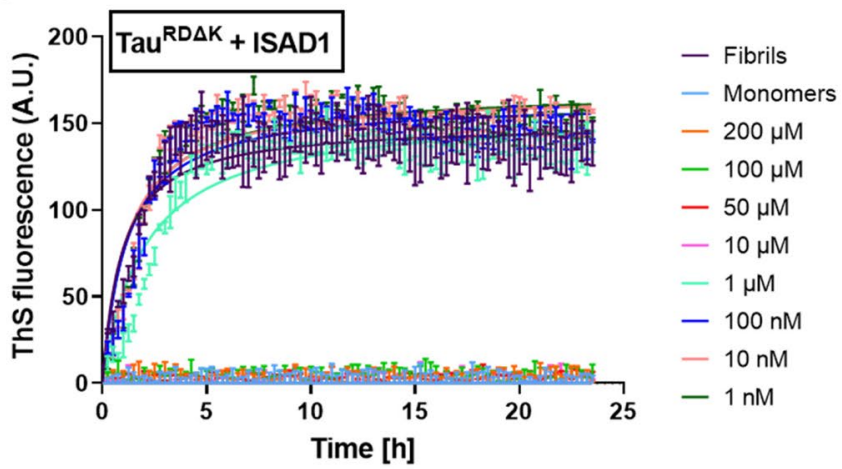

D

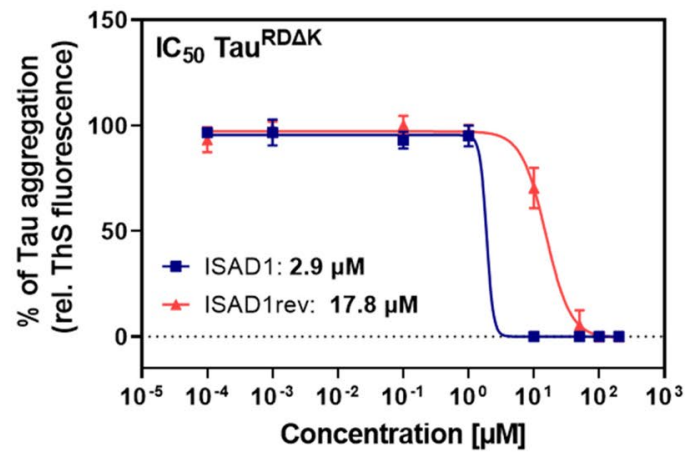

Fig. 4 (See legend on previous page.) 

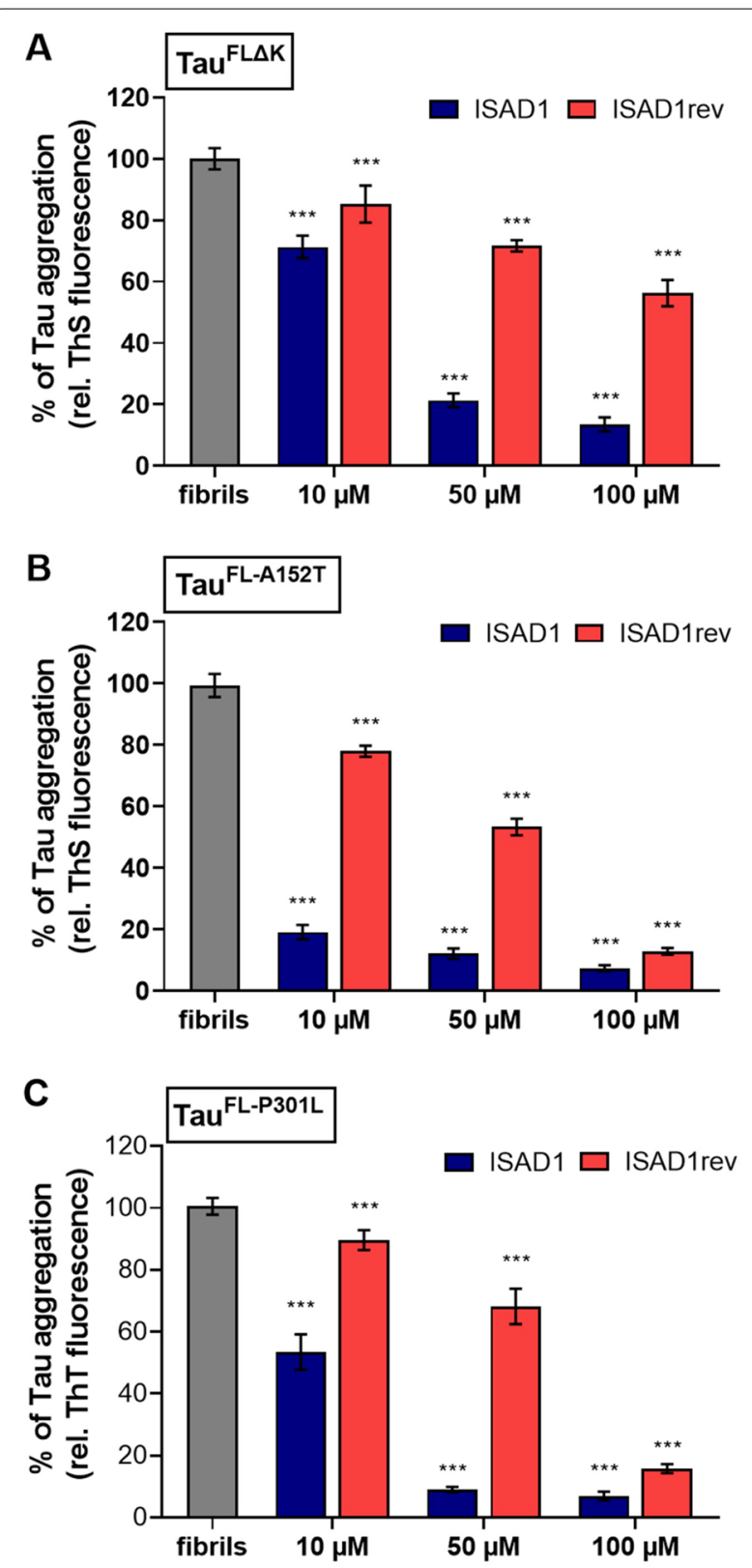

Fig. 5 Inhibition of fibril formation of different Tau mutants in the presence of ISAD1 and ISAD1 rev. For the fibrillization assay, $10 \mu \mathrm{M}$ of each Tau mutant was diluted with $2.5 \mu \mathrm{M}$ heparin and $20 \mu \mathrm{M}$ ThS in BES buffer. The D-peptides ISAD1 and ISAD1 rev were added to and incubated at $37^{\circ} \mathrm{C}$ for $24 \mathrm{~h}$. The fluorescence was measured every $30 \mathrm{~min}$. The fluorescence of the respective Tau control after $24 \mathrm{~h}$ was set as 100\%, and the values and standard deviations of the other incubations are given as percentages of this maximum value. A Inhibition of Tau ${ }^{\mathrm{FL} \Delta \mathrm{K}}$ fibrillization by ISAD1 peptides $[n=3$; one-way ANOVA with Tukey's post hoc test; $\left.F(6,56)=691 ;{ }^{* * *} p \leq 0.001\right]$. B ISAD1 and ISAD1 rev inhibit the fibrillization of Tau ${ }^{\mathrm{FL}-\mathrm{A} 152 \mathrm{~T}}[n=3$; one-way ANOVA with Tukey's post hoc test; $F(6,56)=2455 ;{ }^{* * *} p \leq$ 0.001]. C ISAD1 peptides show inhibition of Tau ${ }^{\mathrm{FL}-\mathrm{P} 301 \mathrm{~L}}$ fibrillization. Significant differences are shown with respect to the respective Tau isoform control (gray) $[n=3$; one-way ANOVA with Tukey's post hoc test; $\left.F(6,56)=809 ;{ }^{* * *} p \leq 0.001\right]$ mutant Tau aggregation (Fig. 5A-C). ISAD1rev showed only weak inhibitory effects (Fig. 5A-C).

In summary, ISAD1 peptide strongly inhibited fiber growth approximately equally well, for $\mathrm{Tau}^{\mathrm{FL}}$ or $\mathrm{Tau}^{\mathrm{RD} \Delta \mathrm{K}}$ repeat domain, with or without mutation. This is consistent with the model (Fig. 3) that the structures of the growing ends of fibers are similar, and similarly disrupted by the side chains on the inside of the two juxtaposed beta sheets.

\section{ISAD1 and ISAD1 rev promote the formation of high molecular weight oligomers of $\mathrm{Tau}^{\mathrm{RD} \Delta \mathrm{K}}$}

We next tested the nature of the non-fibrillar aggregates formed under the conditions described above by DLS and pelleting assay. As shown in Fig. 6A, in the absence of $\mathrm{D}$-peptide, $\mathrm{Tau}^{\mathrm{RD} \Delta \mathrm{K}}$ forms aggregates in the size range of $30-90 \mathrm{~nm}$. Tau monomers are in the size range of $<10 \mathrm{~nm}$. In the presence of ISAD1 and ISAD1rev, the size of these aggregates significantly increased ( 2000-6000 $\mathrm{nm}$ in size). In support of the DLS data, pelleting assay also demonstrated a higher amount of pelletable material in the presence of D-peptides than in the control samples (Fig. 6C, D). Similarly, all full-length disease-relevant Tau mutants $\left(\mathrm{Tau}^{\mathrm{FL} \Delta \mathrm{K}}, \mathrm{Tau}^{\mathrm{FL}-\mathrm{A} 152 \mathrm{~T}}, \mathrm{Tau}^{\mathrm{FL}-\mathrm{P} 301 \mathrm{~L}}\right.$; Sup. Figs. 4-6) in the presence of ISAD1 formed high molecular weight oligomers with a size of $1000-8000 \mathrm{~nm}$. Its inversed form did not induce the formation of high molecular weight oligomers of Tau mutants, as the formed aggregates were in the range of $\sim 20-150 \mathrm{~nm}$ in size similar to heparin-induced fibrils (Sup. Figs. 4-6). The pelleting assays support the data from DLS confirming that ISAD1 induces high molecular weight oligomers presumably non-fibrillar as they are $\mathrm{ThS}$ negative (Fig. 6B) (Sup. Fig. 4B-C, Sup. Fig. 5B-C; Sup. Fig. 6B-C). As control, D-peptides alone in the presence of heparin did not form larger aggregates (Sup. Fig. 7).

\section{N2a-Tau ${ }^{\mathrm{RD} \Delta \mathrm{K}}$ cells actively internalize $\mathrm{D}$-peptides}

In order to become potentially suitable for therapeutic development, the D-peptides should be internalized by neurons. To test this, $25 \mu \mathrm{M}$ FAM-labeled ISAD1 or its inversed form was added to cells that express pro-aggregant mutant $\mathrm{Tau}^{\mathrm{RD} \Delta \mathrm{K}}$ for $24 \mathrm{~h}$ followed by cell fixation. The fixed cells were imaged by confocal microscopy, revealing that almost all cells took up the D-peptides (Fig. 7). Both ISAD1 and ISAD1rev accumulated in the cytosol but were excluded from the nucleus (Fig. 7: A3, B3).

\section{The D-peptides are not toxic to $\mathrm{N} 2 \mathrm{a}-\mathrm{Tau}^{\mathrm{RD} \Delta \mathrm{K}}$ cells even at elevated concentrations}

To find out whether the peptides cause toxic effects in $\mathrm{N} 2 \mathrm{a}-\mathrm{Tau}{ }^{\mathrm{RD} \Delta \mathrm{K}}$ cells, we treated the cells with different 
concentrations of ISAD1 and its inversed version for 24 $h$. The cell viability and membrane integrity were tested by MTT and LDH assays, respectively. Figure $8 \mathrm{~A}$ and B show that the peptides have no effect on these parameters even at higher concentrations up to $250 \mu \mathrm{M}$.

\section{The ISAD1 and ISAD1 rev peptides prevent cell toxicity induced by Tau aggregates}

Tau aggregates in their fibrillar form (PHFs) are toxic to cells when treated extracellularly and cause reactive oxygen species production [21, 22, 34]. Therefore, we tested whether high molecular weight Tau oligomers formed in the presence of D-peptides still have the toxic effects of Tau, as judged by MTT, LDH, and ROS assays. We observed that Tau aggregates formed in the absence of $\mathrm{D}$-peptides caused a reduction in the cell viability (Fig. 9A; light blue bar), compromised cell membrane integrity (Fig. 9B; light blue bar), and increased ROS production (Fig. 9C; light blue bar). Tau high molecular weight oligomers formed in the presence of ISAD1 (dark blue bar) or its inversed form (red bar) do not induce toxicity, as we observed no significant compromise in cell viability (Fig. 9A), cell membrane integrity (Fig. 9B), and ROS production (Fig. 9C) compared to respective controls.

To investigate the effect of D-peptides on inducible $\mathrm{N} 2 \mathrm{a}$ cells expressing $\mathrm{Tau}^{\mathrm{RD} \Delta \mathrm{K}}\left(\mathrm{N} 2 \mathrm{a}-\mathrm{Tau}^{\mathrm{RD}} \Delta \mathrm{K}\right)$, we incubated the cells with the respective D-peptides in the presence of Dox and quantified the cell viability by MTT and LDH assays (Fig. 10). The metabolic activity of the compound-untreated control (gray bar) was set to $100 \%$. The bar diagrams show the relative metabolic activity (Fig. 10A) and LDH release (Fig. 10B) of cells when treated with increasing amounts of ISAD1 and ISAD1rev for $72 \mathrm{~h}$. After incubation with D-peptides, there was an increase in cell viability starting from $100 \mu \mathrm{M}$ concentration, whereas treatment with $50 \mu \mathrm{M}$ shows no increase in cell viability.
Taken together, the results show that the D-peptides are highly tolerable by cells and prevent Tau-induced toxicity by promoting Tau to form non-fibrillar high-n oligomers rather than amyloid-like fibers.

\section{Discussion}

Even through Alois Alzheimer characterized AD more than 100 years ago, there is currently no curative treatment available. These circumstances and the predicted steady increase in the number of AD patients highlight the urgency of developing a causal AD therapy. Recently, the $A \beta$ antibody aducanumab obtained preliminary approval from the FDA. Nevertheless, the approval is controversial and the efficacy of aducanumab has to be proven in further studies [29-31]. A number of potential therapeutic substances targeting the $A \beta$ pathology appeared successful in pre-clinical models, but failed in clinical trials [64-66].

Apart from the amyloid peptide $A \beta$, another compelling target for $\mathrm{AD}$ therapy is Tau. A large body of evidence suggests that Tau pathology has a strong correlation with the disease progression and clinical symptoms [32], which has led to increased research into Tau-associated compounds $[35,67,68]$. Tau pathology not only occurs in AD but also in other neurological diseases, called tauopathies $[69,70]$. The use of small D-amino acid peptides to prevent the pathological fibrillization of Tau may provide an alternative to small molecule non-peptide compounds $[71,72]$. D-peptides are proven to be protease stable and less immunogenic than L-peptides which make them suitable for in vivo applications. The novel D-amino acid peptides we described here inhibited the aggregation not only of $\mathrm{Tau}^{\mathrm{FL}}$, but also of disease-relevant Tau mutants.

ISAD1 and its synthesized reversed form show binding to both non-fibrillized $\mathrm{Tau}^{\mathrm{FL}}$ and filaments of $\mathrm{Tau}^{\mathrm{FL}}$ in ELISA studies. Both D-peptides bind to Tau ${ }^{\mathrm{FL}}$ filaments with an estimated $\mathrm{EC}_{50}$ in the low micromolar range (Fig. 1). We found that ISAD1 binds to the PHF6

\footnotetext{
(See figure on next page.)

Fig. 6 ISAD1 and ISAD1 rev induce the formation of large Tau high-n oligomers, measured by DLS and pelleting assay. A Samples for DLS measurements were prepared with $10 \mu \mathrm{M}$ Tau ${ }^{\mathrm{RD} \Delta \mathrm{K}}, 2.5 \mu \mathrm{M}$ heparin, and $20 \mu \mathrm{M}$ ThS. The peptides were added in a concentration of $100 \mu \mathrm{M}$. All samples were incubated for $24 \mathrm{~h}$. DLS was performed by $25^{\circ} \mathrm{C}$ with an equilibration time of 2 min and 3 measurements within 15 runs. The average of the results is shown as a volume graph. Tau ${ }^{\mathrm{RD} \Delta \mathrm{K}}$ monomer shows a hydrodynamic size of $<10 \mathrm{~nm}$ (blue curve). When Tau is incubated with heparin, larger aggregates (PHF-like fibrils) with a size between 15 and $100 \mathrm{~nm}$ are formed (red curve). In the presence of ISAD1 and ISAD1 rev, even larger high-n oligomers are formed, with a size of 1500-5000 nm (black and green curve), but without $\beta$-structure. B In general, fibrillization of monomeric Tau to fibrils is a multistep process that involves the formation of various aggregates, including protofibrillar oligomers. In the presence of ISAD1 peptides, Tau forms non-toxic clump-shaped high molecular oligomers. CWestern blot of SDS-gels showing proteins in pellets (P) and supernatant (S) when $10 \mu \mathrm{M}$ Tau was incubated with $100 \mu \mathrm{M}$ peptide ISAD1 or ISAD1 rev. After 24 h of Tau fibrillization, samples were centrifuged and the supernatant was separated from the pellet. The western blot was detected by the antibody K9JA. Tau ${ }^{\text {RD } \Delta K}$ fibrils resolved on SDS-gels show fractions in the supernatant $(S)$ and pellet $(P)$ after centrifugation (lanes 1,2). Due to the high molecular oligomers which are formed in the presence of the D-peptides, there are only apparent in the pellet (lanes 3-6). D The quantification of the western blot was performed using ImageJ. The intensity of protein amount in supernatant and pellet of the fibrils was set as 100\%. There is a difference between the Tau fibrils and D-peptide-treated supernatant and pellet fractions
} 

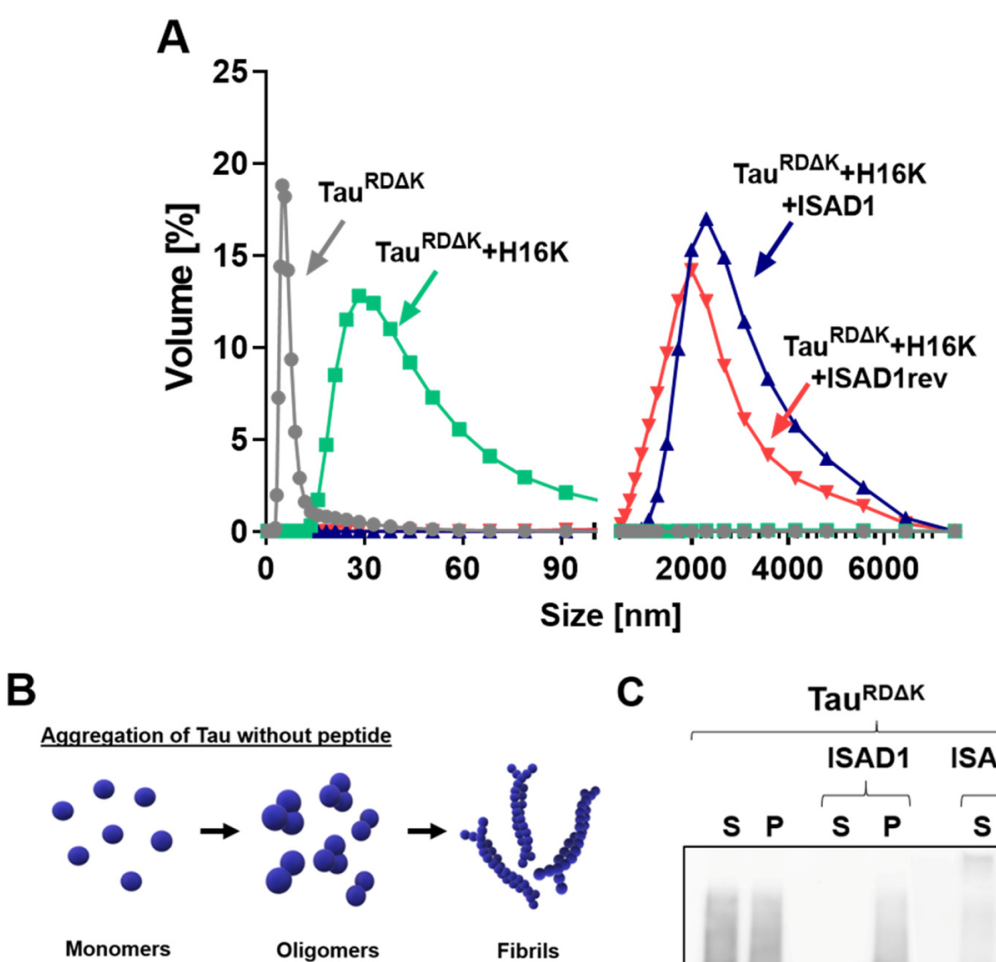

C
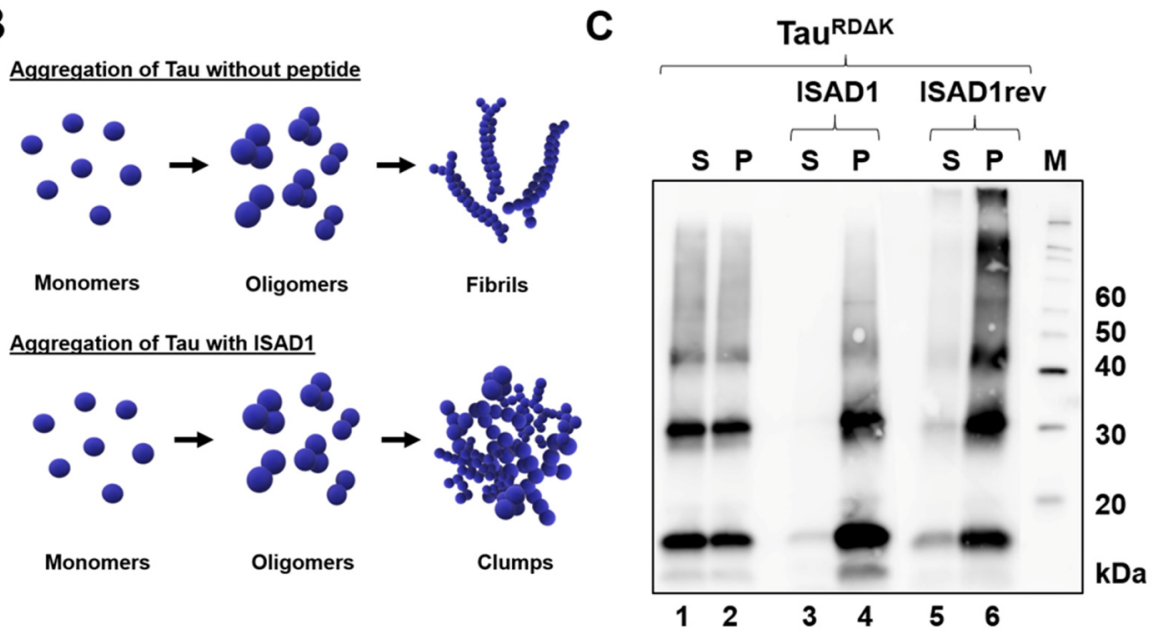

D

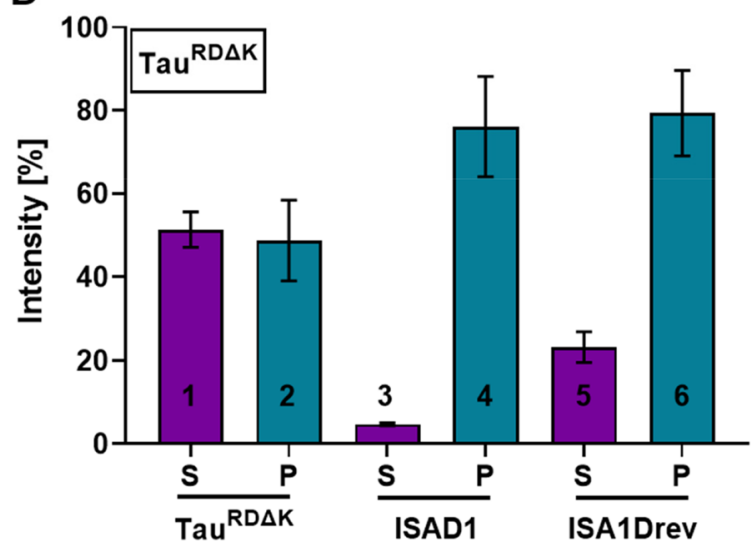

Fig. 6 (See legend on previous page.) 

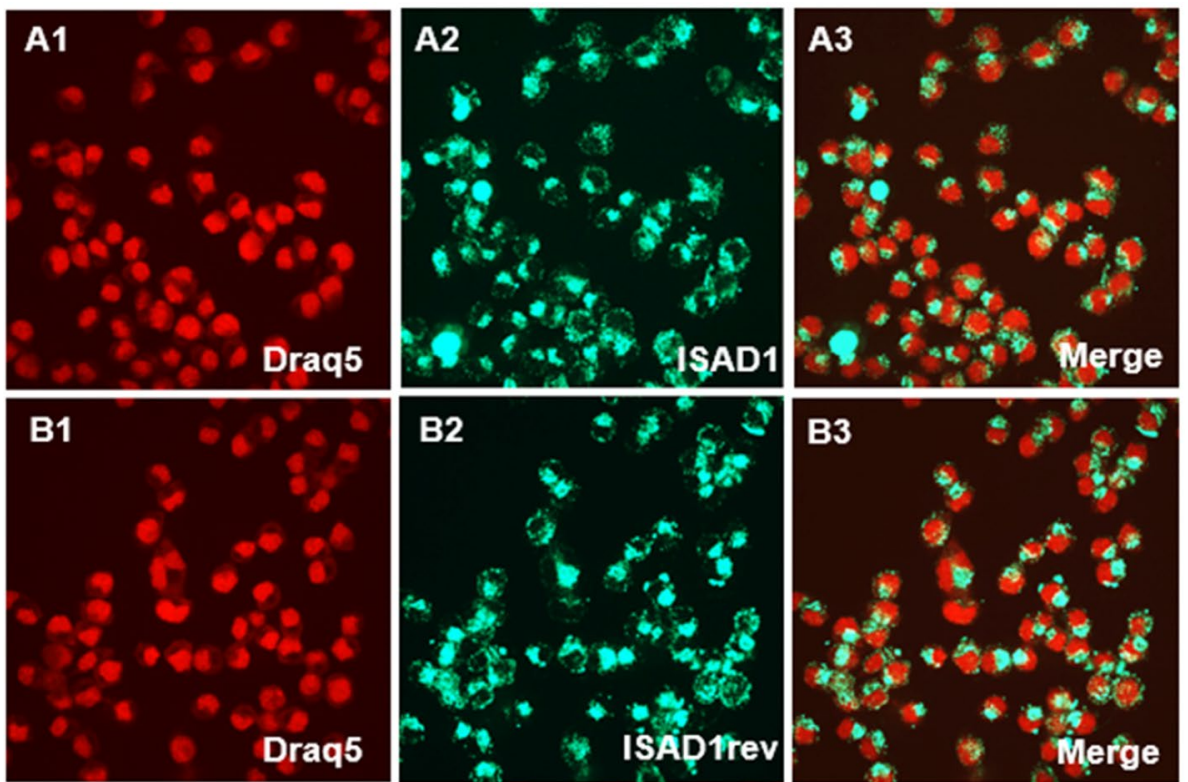

Fig. 7 Uptake of fluorescence-labeled D-peptides analyzed by confocal microscopy. $25 \mu \mathrm{M}$ FAM-labeled peptides (ISAD1 and ISArev) were incubated with N2a cells expressing Tau ${ }^{\mathrm{RD} \Delta \mathrm{K}}$ for $24 \mathrm{~h}$. The uptake of D-peptides was analyzed by confocal microscopy. As shown in the representative images, the peptides are mainly localized in the cytoplasm (A1, B1 Draq5 shown as red; A2 ISAD1-FAM, B2 ISAD1 rev-FAM; A3, B3 merged images)

motif of Tau (Sup. Fig. 3A) and inhibits the fibrillization of PHF6, but not of PHF6" despite the close vicinity and high sequence similarity of these two hexapeptides. PHF6 ( $\left.{ }_{306} \mathrm{VQIVYK}_{311}\right)$ is known to strongly promote Tau aggregation into $\beta$-structured filaments [6, 7], while most other parts Tau protein are unstructured. This could be the reason why phages in the selection process bind more preferentially to this structured sequence motif.

We illustrated the binding mode of ISAD1 to PHF6 fibrils by in silico modeling according to previously described Tau aggregation inhibitor peptides $[9,50]$ selected against PHF6. The modeling data indicated a similar sequence motif and binding mode in blocking PHF6 fibrillization as previously described PHF6addressing D-peptides TLKIVW [9] and TD28 [50]. The modeling demonstrated the similarity between the three D-peptide complexes with PHF6. The formation of stabilizing backbone hydrogen bonds to PHF6 is allowed by binding in parallel $\beta$-sheet conformation. Since the interface is formed between a D- and L-peptide, a rippled $\beta$-sheet is created [73] which was shown by quantum chemistry calculations to exhibit favorable interaction energies in the PHF6 system [74]. A second effect, which blocks lateral fibril growth, results from the steric repulsion between the D-peptides and the second stack of $\beta$-strands (Fig. 3). It has been suggested that such steric repulsion between L2 in TLK or M6 in TD28, respectively, and V306'/I308' of the second stack of $\beta$-strands represents key feature blocking further fibril growth [9, 50]. For ISAD1, the corresponding residue F3 shows a similar spatial orientation that may lead to a similar effect preventing the fibril or oligomers from further growth. Notably, this sequence motif was absent in the PHF6*binding peptides MMD3 and MMD3rev reported in Malhis et al. [52].

Our NMR data show that ISAD1 does bind Tau monomers in solution only moderately. Since the ELISA was carried out with high local concentrations of Tau that could lead to oligomerization, it is likely that Tau was immobilized as a mixture of monomeric and oligomeric forms, and the affinity measured by ELISA reflects the binding of ISAD1 to this mixture. The NMR spectra also support the claim that ISAD1 promotes the formation of high molecular weight oligomers of Tau. The reference $\mathrm{Tau}^{\mathrm{FL}}$ spectrum contained a mixture of monomeric and oligomeric Tau, oligomer formation being favored in the absence of reducing agents. No marked increase in $I / I_{\mathrm{o}}$ values was evident and there are generally many $I / I_{\mathrm{o}}$ values below 1 especially for the mole ratio 1:30 Tau:ISAD1 (Sup. Fig. 2B). This suggests that at high concentrations of ISAD1 the affinity of ISAD1 for monomeric Tau is moderate, and Tau oligomer formation is favored in the presence of ISAD1. 


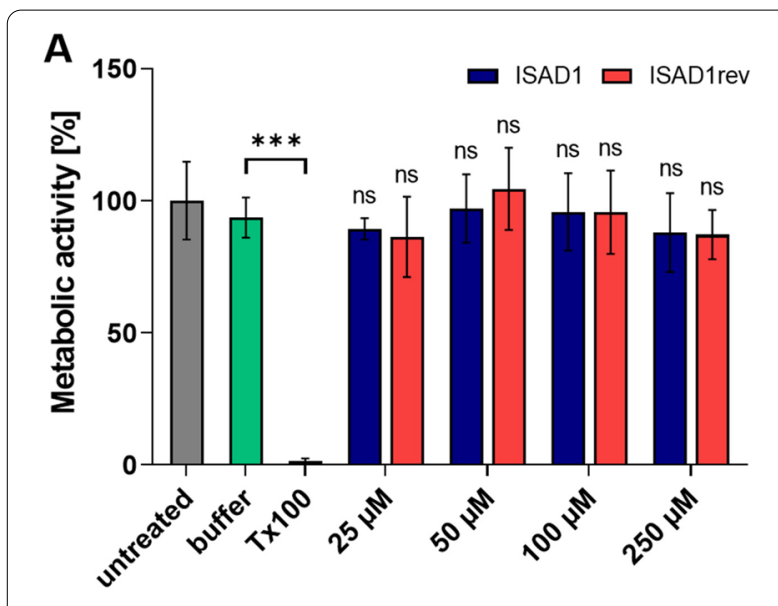

B

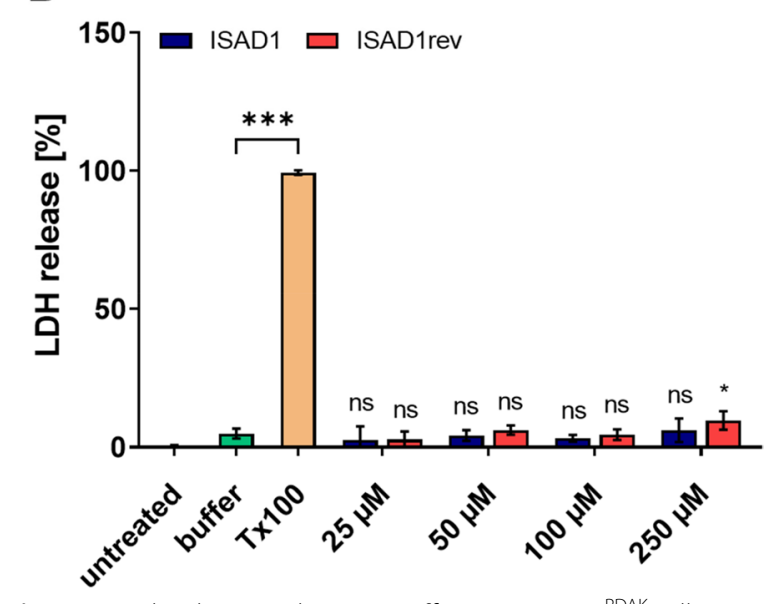

Fig. 8 Peptides do not induce toxic effects in N2a-Tau ${ }^{\mathrm{RD} \Delta \mathrm{K}}$ cells. A MTT-based cytotoxicity assay in the presence of ISAD1 and ISAD1 rev peptides. Different peptide concentrations $(25,50,100,250 \mu \mathrm{M})$ were tested on N2a-Tau ${ }^{\mathrm{RD} \Delta \mathrm{K}}$ cells over $24 \mathrm{~h}[n=3$; one-way ANOVA with Tukey's post hoc test; $\left.F(10,151)=101 ;{ }^{* * *} p \leq 0.001\right]$. $\mathbf{B} \mathrm{LDH}$ release of N2a-Tau ${ }^{\mathrm{RD} \Delta \mathrm{K}}$ cells treated with ISAD1 peptides for $24 \mathrm{~h}[n=3$; one-way ANOVA with Tukey's post hoc test; $F(10,88)=1050$; ${ }^{*} p \leq$ $\left.0.05 ;{ }^{* * *} p \leq 0.001\right]$.

Aggregation of Tau is the primary hallmark for the disease pathology in $\mathrm{AD}$ and other tauopathies. A significant inhibition of the aggregation by therapeutic molecules is considered beneficial. Our novel peptide ISAD1 inhibited the fibrillization of $\mathrm{Tau}^{\mathrm{FL}}$ and pro-aggregant $\mathrm{Tau}^{\mathrm{RD}} \Delta \mathrm{K}$ $\left(\mathrm{IC}_{50}\right.$ of $\left.\sim 3 \mu \mathrm{M}\right)$ in concentrations which are typical for peptide inhibitors. Interestingly, ISAD1 inhibited fibrillization of Tau more efficiently than other PHF6 addressing peptides: TLKIVW $54.1 \mu \mathrm{M}$ [9] and APT $5.9 \mu \mathrm{M}$ [50].

Familial mutations of Tau cause the rapid aggregation and progression of the diseases. This makes it necessary to find a D-peptide that can inhibit the aggregation of such pro-aggregant mutants of Tau. To date, only our D-peptides have been proven to simultaneously inhibit the aggregation of three pro-aggregant Tau forms $\left(\mathrm{Tau}^{\mathrm{FL} \Delta \mathrm{K}}, \mathrm{Tau}^{\mathrm{FL}-\mathrm{A} 152 \mathrm{~T}}\right.$, Tau $\left.{ }^{\mathrm{FL}-\mathrm{P} 301 \mathrm{~L}}\right)$ found in FTD, AD, PSP, and FTDP-17 diseases (Fig. 5A-C) in a concentration-dependent manner which makes our D-peptides unique and proves their therapeutic potential. Mutations $\Delta \mathrm{K} 280$ and P301L are each located on R2 of the repeat domain, close to a possible binding site of ISAD1 while mutation A152T is located in the proline-rich domain within Tau. The inhibitory potencies are almost the same for $\mathrm{Tau}^{\mathrm{FL}}$ and $\mathrm{Tau}^{\mathrm{RD} \Delta \mathrm{K}}\left(\mathrm{IC}_{50}\right.$ of $\left.2.9 \mu \mathrm{M}\right)$, despite the fact that the two Tau constructs have different aggregation efficiencies.

Based on DLS and pelleting assays, we observed that the ISAD1 and its reversed form prevent fiber formation of $\mathrm{Tau}^{\mathrm{FL}}$ and $\mathrm{Tau}{ }^{\mathrm{RD} \Delta \mathrm{K}}$ and instead induce the formation of higher molecular weight off-pathway Tau oligomers (Fig. 6B) which are non-fibrillar in nature (ThS negative), similar to other previously described peptides [43, 52]. We had demonstrated by atomic force microscopy (AFM) that in case of the MMD3 peptide, the aggregates formed are amorphous clumps of off-pathway high-n oligomers [52] which cause large signals in DLS experiments, also observed for the ISAD1and its reversed form.

In order to be used as a therapeutic agent for neurodegenerative diseases, the D-peptides need to cross the blood-brain barrier (BBB), should be actively taken up by neurons, and should be non-toxic to brain cells. Peptides do in general not cross membranes very well, but the naturally occurring transcription factor domain penetratin, HIV-Tat, or synthetic cationic peptides have been described as cell penetrating peptides [75-77].

Interestingly, D-peptides investigated previously have also been shown to cross the BBB in combination with high bioavailability and drug exposure to the brain [45]. The novel D-peptides developed in this study were demonstrated to cross the membranes of N2a-Tau ${ }^{\mathrm{RD} \Delta \mathrm{K}}$ cells efficiently (Fig. 7), although the mechanism of penetration is still unclear. Since the N2a-Tau ${ }^{\mathrm{RD}} \Delta \mathrm{K}$ cells take up the peptides uniformly, we assume that the uptake of the peptides occurs through bulk endocytosis. Our D-peptides neither caused a change in cell viability (Fig. 8A) nor cell membrane integrity (Fig. 8B) even at high concentrations, suggesting high tolerability by neuronal cells. Additionally, ISAD1 and its reversed form prevented the cytotoxic potential of Tau aggregates by promoting offpathway high-n oligomers, evident from the enhanced cell viability (Fig. 9A) in N2a-Tau ${ }^{\mathrm{RD} \Delta \mathrm{K}}$ cells, improved cell membrane integrity (Fig. 9B), and prevent the ROS elevation (Fig. 9C). Compared to other Tau-derived peptides previously published [78-80], ISAD1 demonstrates similar prevention of toxicity by maintaining cell viability and metabolic activity also in the presence of cellular $\mathrm{Tau}^{\mathrm{RD}} \Delta \mathrm{K}$ 

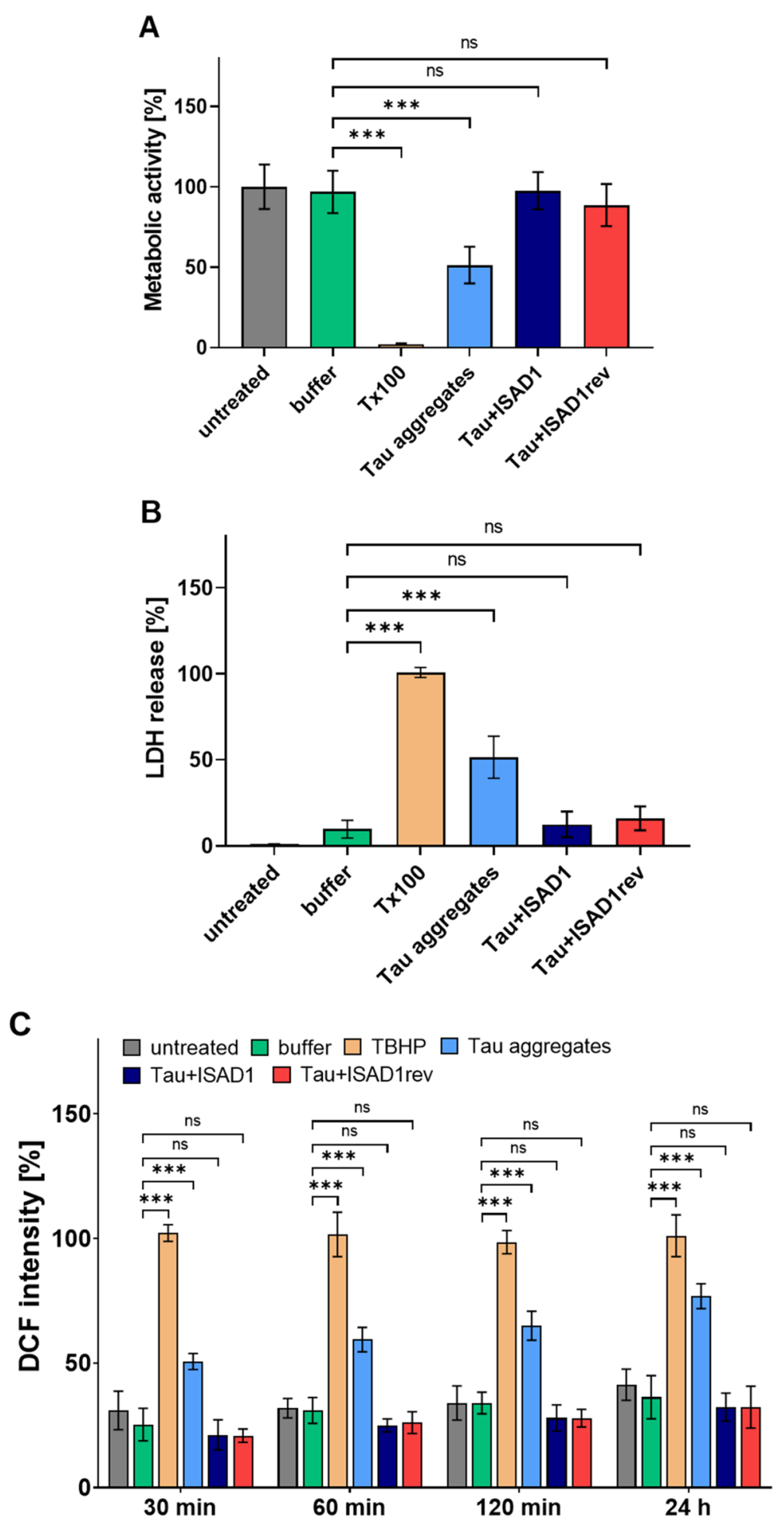

Fig. 9 ISAD1 and ISAD1 rev prevent toxic effects of Tau aggregates. $200 \mu \mathrm{M}$ of Tau ${ }^{\mathrm{RD} \Delta \mathrm{K}}$ was incubated with or without peptides (1:10) respectively for $24 \mathrm{~h}$ at $37^{\circ} \mathrm{C}$. Pre-incubated samples $\left(10 \mu \mathrm{M}\right.$ Tau, $100 \mu \mathrm{M}$ peptide final concentration) were added to N2a-Tau ${ }^{\mathrm{RD} \Delta \mathrm{K}}$ cells followed by recording of MTT, LDH, and ROS intensities. A Pre-incubated Tau with peptides inhibit Tau toxic effects by preserving cell viability (blue and red bars) $[n=3$; one-way ANOVA with Tukey's post hoc test; $\left.F(5,48)=102 ;{ }^{* * *} p \leq 0.001\right]$. B Low LDH release levels show protection of cell membrane integrity by peptides (blue and red bars) $\left[n=3\right.$; one-way ANOVA with Tukey's post hoc test; $\left.F(5,48)=268 ;{ }^{* *} p \leq 0.001\right]$. C Within 30 min, the cells increase ROS level in the aggregate-treated cells (light blue bar). Pre-incubated Tau with peptides inhibit Tau toxic effects in reducing intracellular ROS levels (blue and red bars) compared to positive control TBHP (beige bar) $[n=3$; one-way ANOVA with Tukey's post hoc test; $F(23,192)=209 ; * * * \leq 0.001]$ 


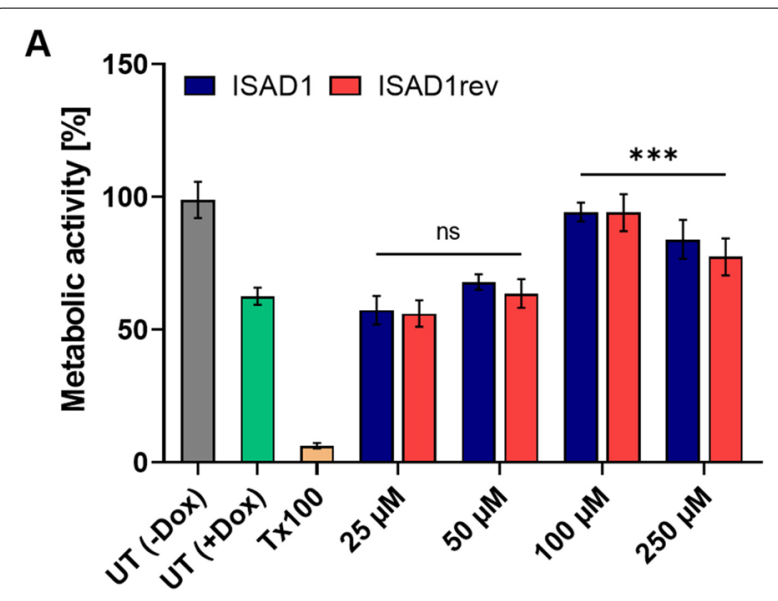

B

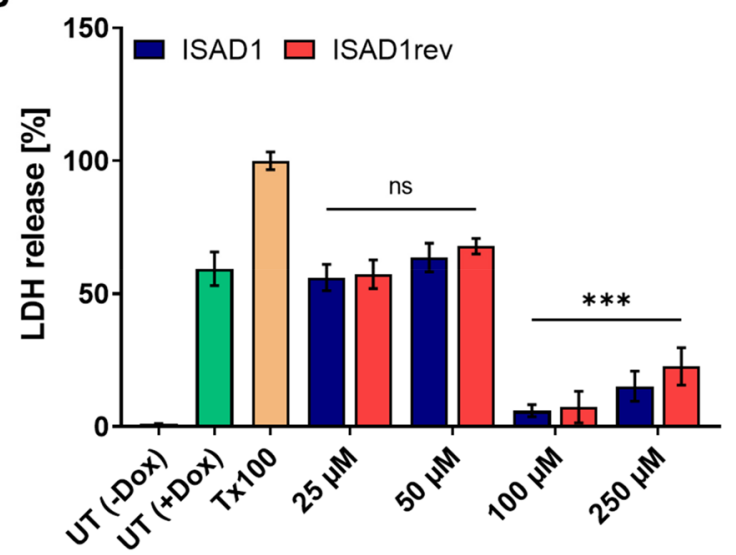

Fig. 10 ISAD1 and ISAD1 rev reduce toxic effects of intracellularly expressed Tau ${ }^{\mathrm{RD} \Delta K}$ aggregates. Expression of Tau ${ }^{\mathrm{RD} \Delta \mathrm{K}}$ in N2a cells was induced by adding $1 \mathrm{\mu g} / \mathrm{ml}$ doxycycline. The cells were incubated with different concentrations of ISAD1 and ISAD1 rev $(25,50,100$, $250 \mu \mathrm{M})$ for $24 \mathrm{~h}$ at $37^{\circ} \mathrm{C}$ followed by determination of MTT and $\mathrm{LDH}$ intensities. A Peptides prevent intracellular toxic Tau effects by preserving metabolic activity from $100 \mu \mathrm{M}$ concentration (blue and red bars) similar to untreated cells (gray bar, UT -Dox) $[n=2$; one-way ANOVA with Tukey's post hoc test; $\left.F(11,60)=126 ;{ }^{* * *} p \leq 0.001\right]$. B Protection of cell membrane integrity by D-peptides (blue and red bars) determined by $L D H$ release $[n=2$; one-way ANOVA with Tukey's post hoc test; $\left.F(11,60)=256 ;{ }^{* *} p \leq 0.001\right]$.

expression. The N2a-Tau ${ }^{\mathrm{RD} \Delta \mathrm{K}}$ cell model of Tau pathology is well established and useful in the screening and study of therapeutic compounds, such as Tau aggregation inhibitors $[81,82]$. Earlier studies with N2a-Tau ${ }^{R D} \Delta K$ cells had shown a time-dependent increase in cell death [81]. In N2a-Tau ${ }^{\mathrm{RD} \Delta \mathrm{K}}$ cells, the expression of $\mathrm{Tau}^{\mathrm{RD} \Delta \mathrm{K}}$ starts at $24 \mathrm{~h}$ after protein induction and its overexpression is the trigger for dimerization and aggregation. The treatment of N2a-Tau ${ }^{\mathrm{RD} \Delta \mathrm{K}}$ cells with ISAD1 and its reversed form decreased the toxicity of cellular $\operatorname{Tau}^{\mathrm{RD}} \Delta \mathrm{K}$ in a dose-dependent manner, as seen by the parameters of cell viability and LDH release (Fig. 10). This demonstrates that toxic effects of $\mathrm{Tau}{ }^{\mathrm{RD}} \Delta \mathrm{K}$ aggregates can be suppressed by the D-peptides.

In conclusion, especially our novel $\mathrm{D}$-amino acid peptide ISAD1 inhibits fibril formation of pro-aggregant toxic Tau, is non-toxic to cells, and prevents the toxic effects of Tau by promoting off-pathway aggregate formation which makes our D-peptide a potential therapeutic molecule to prevent Tau pathology in AD and other Tau-associated diseases. However, ISAD1rev might have a limited therapeutic potential due to significant lower inhibition of Tau aggregation. More details like BBB transfer and the efficacy of ISAD1 have to be investigated in future in vivo treatment studies to further elucidate the peptide mechanism of action and its full therapeutic potential.

\section{Limitations}

This report has some limitations. The study resulted in very promising findings in vitro and in cell culture; however, BBB permeability and efficiency in vivo still need to be investigated.

\section{Conclusion}

Taken together, using phage display with immobilized $\mathrm{Tau}^{\mathrm{FL}}$, we have found novel D-amino acid peptides, which inhibited the fibrillization of $\mathrm{Tau}^{\mathrm{FL}}$. One of our selected D-amino acid peptides, ISAD1, showed the most promising characteristics in several in vitro experiments. We found that ISAD1 was able to bind to Tau ${ }^{\mathrm{FL}}$ regardless of its conformation. PHF6 was identified as a possible binding site of ISAD1, binding here in the same mode as already known PHF6 targeting peptides. ISAD1 modulated Tau fibrillization towards nontoxic, non-fibrillar aggregates and therefore rescued cells from Tau-derived toxicity. Additionally, our D-amino acid peptides inhibited the fibrillization of diseaserelevant Tau mutants which gives them an extended field of application. The D-amino acid conformation will enable high proteolytic stability of the peptides in vivo. Further investigations including in vivo studies should provide more information about the mechanism how ISAD1 modulates Tau, and should investigate BBB transfer to elaborate the full therapeutic potential.

\section{Abbreviations}

AA: Amino acids; AD: Alzheimer's disease; AFM: Atomic force microscopy; $A \beta$ : Amyloid-beta; BBB: Blood-brain barrier; BCA: Bicinchoninic acid; BSA: Bovine serum albumin; D3: A $\beta$-binding peptide; Da: Dalton; DCF: Dichlorodihydrofluorescein; DLS: Dynamic light scattering; Dox: Doxycycline; DTT: Dithiothreitol; ELISA: Enzyme-linked immunosorbent assay; FAM: Fluorescein amidites; FBS: Fetal bovine serum; FDA: Food and Drug Administration; FITC: Fluorescein isothiocyanate; FTDP-17: Parkinsonism linked to chromosome 17; G418: Geneticin; H16K: Heparin 16000; HRP: Horseradish peroxidase; Hyg: Hygromycin; LDH: Lactate dehydrogenase; MEM: Minimum essential medium; 
MT: Microtubules; N2a: Neuronal-2a cell line; NFTs: Neurofibrillary tangles; PBS: Phosphate-buffered saline; PBST: Phosphate-buffered saline with Tween20; PHFs: Paired helical filaments; PSP: Progressive supra-nuclear palsy; PVDF: Polyvinylidene fluoride; RD: Repeat domain; RD2: Peptide derivate of D3; ROS: Reactive oxygen species; RT: Room temperature; SDS-PAGE: Sodium dodecylsulfate polyacrylamide gel electrophoresis; Tau ${ }^{\mathrm{FL}}$ : Full-length human Tau (441 AA); TauFL ${ }^{F L K}$ : Full-length Tau mutant $\triangle K 280 ;$ Tau ${ }^{F L-A 152 T}$ : Full-length Tau mutant A152T; Tau FL-P301L: Full-length Tau mutant P301L; Tau RD ${ }^{\text {RKK }}$ : Pro-aggregant repeat domain Tau mutant $\triangle K 280$; TBHP: Tert-butylhydroperoxide; TBS: Tris-buffered saline; TBST: Tris-buffered saline with Tween20; ThT: Thioflavin-T; ThS: ThioflavinS; TMB: Tetramethylbenzidine; TUP: Target-unrelated peptide; UT: Untreated.

\section{Supplementary Information}

The online version contains supplementary material available at https://doi. org/10.1186/s13195-022-00959-z.

Additional file 1. Supplementing Data.

\section{Acknowledgements}

We would like to thank Sabrina Huebschmann and Jacek Biernat for preparing the proteins, and we would also like to thank Dr. Anja Schneider for kindly allowing us to perform the cell culture experiments in her lab.

\section{Authors' contributions}

The acquisition of funding and project administration was provided by SAF, $E M$, and MZ. SAF, EM, IA, and SK did the overall strategic planning and design of the study. SAF, IA, SK, and RRC planned the details of the studies. Peptide synthesis was performed by SA, supervised by JE. IA and SK have written major parts of the manuscript. SK and RRC have designed and IA has performed the DLS and cell culture experiments. The molecular modeling was performed by $\mathrm{AHCH}$ and HS. The NMR measurements were designed and performed by LMR and MZ. All authors have contributed to the manuscript text. The authors read and approved the final manuscript.

\section{Authors' information}

Not applicable.

\section{Funding}

Open Access funding enabled and organized by Projekt DEAL. This work was supported by a grant of Alzheimer Forschung Initiative e.V. (AFI) to SAF (no. 17001), a grant of TechnologieAllianzOberfranken (TAO) to IA, and a scholarship of Landeskonferenz der Frauenbeauftragten (LaKoF), Bavaria, Germany, to IA and a grant of Cure Alzheimer Fund and Katharina Hardt Foundation to EM. M.Z. was supported by the European Research Council (ERC) under the EU Horizon 2020 research and innovation programme (grant agreement no. 787679).

\section{Availability of data and materials}

All relevant data are within the paper and its Supporting Information files. Additional datasets during and/or analyzed during the current study are available from the corresponding author on reasonable request.

\section{Declarations}

\section{Ethics approval and consent to participate}

Not applicable

\section{Consent for publication}

Not applicable

\section{Competing interests}

The authors declare that they have no competing interests.

\section{Author details}

${ }^{1}$ Institute of Bioanalysis, Coburg University of Applied Sciences, Coburg, Germany. ${ }^{2}$ German Center for Neurodegenerative Diseases (DZNE), Bonn, Germany. ${ }^{3}$ Department of Neurodegenerative Diseases and Geriatric Psychiatry,
University of Bonn, Bonn, Germany. ${ }^{4}$ Forschungsgruppe Translationale Strukturbiologie, Deutsches Zentrum für Neurodegenerative Erkrankungen (DZNE), Göttingen, Germany. ${ }^{5}$ Institut für Chemie und Pharmazie, FriedrichAlexander-Universität Erlangen-Nürnberg, Erlangen, Germany. ${ }^{6}$ Bioinformatik, Institut für Biochemie, Friedrich-Alexander-Universität Erlangen-Nürnberg, Erlangen, Germany. ${ }^{7}$ Institut für Medizinische Genetik, Universität Zürich, Zürich, Switzerland. ${ }^{8}$ Abteilung für NMR-basierte Strukturbiologie, Max-PlanckInstitut für Biophysikalische Chemie, Göttingen, Germany. ${ }^{9} \mathrm{CAESAR}$ Research Center, Bonn, Germany.

Received: 31 October 2021 Accepted: 6 January 2022

Published online: 21 January 2022

\section{References}

1. Goedert M. Neurodegeneration. Alzheimer's and Parkinson's diseases: the prion concept in relation to assembled $A \beta$, tau, and a-synuclein. Science. 2015;349:1255555. https://doi.org/10.1126/science.1255555.

2. Alzheimer A. Über eine eigenartige Erkrankung der Hirnrinde. Allgemeine Zeitschrift für Psychiatrie und Psychisch-gerichtliche Medizin. 1907;64:146-8.

3. Drechsel DN, Hyman AA, Cobb MH, Kirschner MW. Modulation of the dynamic instability of tubulin assembly by the microtubule-associated protein tau. Mol Biol Cell. 1992;3:1141-54. https://doi.org/10.1091/mbc.3. 10.1141.

4. Witman GB, Cleveland DW, Weingarten MD, Kirschner MW. Tubulin requires tau for growth onto microtubule initiating sites. Proc Natl Acad Sci U S A. 1976;73:4070-4.

5. Fischer D, Mukrasch MD, Biernat J, Bibow S, Blackledge M, Griesinger C, et al. Conformational changes specific for pseudophosphorylation at serine 262 selectively impair binding of tau to microtubules. Biochemistry. 2009. https://doi.org/10.1021/bi901090m.

6. von Bergen M, Barghorn S, Li L, Marx A, Biernat J, Mandelkow EM, et al. Mutations of tau protein in frontotemporal dementia promote aggregation of paired helical filaments by enhancing local beta-structure. J Biol Chem. 2001;276:48165-74. https://doi.org/10.1074/jbc.M105196200.

7. von Bergen M, Friedhoff P, Biernat J, Heberle J, Mandelkow E-M, Mandelkow E. Assembly of tau protein into Alzheimer paired helical filaments depends on a local sequence motif (306VQIVYK311) forming beta structure. Proc Natl Acad Sci. 2000;97:5129-34. https://doi.org/10.1073/pnas.97.10.5129.

8. Seidler PM, Boyer DR, Rodriguez JA, Sawaya MR, Cascio D, Murray K, et al. Structure-based inhibitors of tau aggregation. Nat Chem. 2018;10:170-6. https://doi.org/10.1038/nchem.2889.

9. Sievers SA, Karanicolas J, Chang HW, Zhao A, Jiang L, Zirafi O, et al. Structurebased design of non-natural amino-acid inhibitors of amyloid fibril formation. Nature. 2011;475:96-100. https://doi.org/10.1038/nature10154.

10. Sawaya MR, Sambashivan S, Nelson R, Ivanova MI, Sievers SA, Apostol MI, et al. Atomic structures of amyloid cross-beta spines reveal varied steric zippers. Nature. 2007;447:453-7. https://doi.org/10.1038/nature05695.

11. Goux WJ, Kopplin L, Nguyen AD, Leak K, Rutkofsky M, Shanmuganandam $V D$, et al. The formation of straight and twisted filaments from short tau peptides. J Biol Chem. 2004;279:26868-75. https://doi.org/10.1074/jbc. M402379200

12. Wille H, Drewes G, Biernat J, Mandelkow EM, Mandelkow E. Alzheimer-like paired helical filaments and antiparallel dimers formed from microtubuleassociated protein tau in vitro. J Cell Biol. 1992;118:573-84. https://doi. org/10.1083/jcb.118.3.573.

13. Goedert M, Jakes R, Spillantini MG, Hasegawa M, Smith MJ, Crowther RA. Assembly of microtubule-associated protein tau into Alzheimer-like filaments induced by sulphated glycosaminoglycans. Nature. 1996:383:5503. https://doi.org/10.1038/383550a0

14. Pérez M, Valpuesta JM, Medina M, Montejo de Garcini E, Avila J. Polymerization of tau into filaments in the presence of heparin: the minimal sequence required for tau-tau interaction. J Neurochem. 1996;67:118390. https://doi.org/10.1046/j.1471-4159.1996.67031183.x.

15. Kampers T, Friedhoff P, Biernat J, Mandelkow E-M, Mandelkow E. RNA stimulates aggregation of microtubule-associated protein tau into Alzheimer-like paired helical filaments. FEBS Lett. 1996;399:344-9. https:// doi.org/10.1016/s0014-5793(96)01386-5. 
16. Wilson DM, Binder LI. Polymerization of microtubule-associated protein tau under near-physiological conditions. J Biol Chem. 1995;270:24306-14. https://doi.org/10.1074/jbc.270.41.24306.

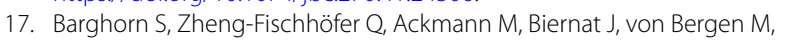
Mandelkow EM, et al. Structure, microtubule interactions, and paired helical filament aggregation by tau mutants of frontotemporal dementias. Biochemistry. 2000;39:11714-21. https://doi.org/10.1021/bi000850r.

18. Lasagna-Reeves CA, Castillo-Carranza DL, Sengupta U, Sarmiento J, Troncoso J, Jackson GR, et al. Identification of oligomers at early stages of tau aggregation in Alzheimer's disease. FASEB J. 2012;26:1946-59. https://doi. org/10.1096/f.11-199851.

19. Maeda S, Sahara N, Saito Y, Murayama M, Yoshiike Y, Kim H, et al. Granular tau oligomers as intermediates of tau filaments. Biochemistry. 2007;46:3856-61. https://doi.org/10.1021/bi061359o.

20. Tian H, Davidowitz E, Lopez P, Emadi S, Moe J, Sierks M. Trimeric tau is toxic to human neuronal cells at low nanomolar concentrations. Int J Cell Biol. 2013;2013:260787. https://doi.org/10.1155/2013/260787.

21. Flach K, Hilbrich I, Schiffmann A, Gärtner U, Krüger M, Leonhardt M, et al. Tau oligomers impair artificial membrane integrity and cellular viability. J Biol Chem. 2012;287:43223-33. https://doi.org/10.1074/jbc.M112.396176.

22. Kaniyappan S, Chandupatla RR, Mandelkow E-M, Mandelkow E. Extracellular low-n oligomers of tau cause selective synaptotoxicity without affecting cell viability. Alzheimers Dement. 2017;13:1270-91. https://doi. org/10.1016/j.jalz.2017.04.002.

23. Conway KA, Baxter EW, Felsenstein KM, Reitz AB. Emerging beta-amyloid therapies for the treatment of Alzheimer's disease. CPD. 2003;9:427-47. https://doi.org/10.2174/1381612033391649.

24. Lobello K, Ryan JM, Liu E, Rippon G, Black R. Targeting Beta amyloid: a clinical review of immunotherapeutic approaches in Alzheimer's disease. Int J Alzheimers Dis. 2012;2012:628070. https://doi.org/10.1155/2012/628070.

25. Chen G-F, Xu T-H, Yan Y, Zhou Y-R, Jiang Y, Melcher K, et al. Amyloid beta: structure, biology and structure-based therapeutic development. Acta Pharmacol Sin. 2017;38:1205-35. https://doi.org/10.1038/aps.2017.28.

26. van Dyck CH. Anti-amyloid- $\beta$ monoclonal antibodies for Alzheimer's disease: pitfalls and promise. Biol Psychiatry. 2018;83:311-9. https://doi. org/10.1016/j.biopsych.2017.08.010.

27. Mehta D, Jackson R, Paul G, Shi J, Sabbagh M. Why do trials for Alzheimer's disease drugs keep failing? A discontinued drug perspective for 2010-2015. Expert Opin Investig Drugs. 2017;26:735-9. https://doi.org/10. 1080/13543784.2017.1323868

28. Oxford AE, Stewart ES, Rohn TT. Clinical trials in Alzheimer's disease: a hurdle in the path of remedy. Int J Alzheimers Dis. 2020;2020:5380346. https://doi.org/10.1155/2020/5380346.

29. Knopman DS, Jones DT, Greicius MD. Failure to demonstrate efficacy of aducanumab: an analysis of the EMERGE and ENGAGE trials as reported by Biogen, December 2019. Alzheimers Dement. 2021;17:696-701. https://doi.org/10.1002/alz.12213.

30. Mullard A. FDA approval for Biogen's aducanumab sparks Alzheimer disease firestorm. Nat Rev Drug Discov. 2021;20:496. https://doi.org/10. 1038/d41573-021-00099-3.

31. Walsh S, Merrick R, Milne R, Brayne C. Aducanumab for Alzheimer's disease? BMJ. 2021;374:n1682. https://doi.org/10.1136/bmj.n1682.

32. Braak H, Braak E. Neuropathological stageing of Alzheimer-related changes. Acta Neuropathol. 1991;82:239-59. https://doi.org/10.1007/ BF00308809.

33. Pascoal TA, Benedet AL, Ashton NJ, Kang MS, Therriault J, Chamoun M, et al. Microglial activation and tau propagate jointly across Braak stages. Nat Med. 2021;27:1592-9. https://doi.org/10.1038/s41591-021-01456-w.

34. Lasagna-Reeves CA, Castillo-Carranza DL, Guerrero-Muoz MJ, Jackson GR, Kayed R. Preparation and characterization of neurotoxic tau oligomers. Biochemistry. 2010;49:10039-41. https://doi.org/10.1021/bi1016233.

35. Bulic B, Pickhardt M, Mandelkow E-M, Mandelkow E. Tau protein and tau aggregation inhibitors. Neuropharmacology. 2010;59:276-89. https://doi. org/10.1016/j.neuropharm.2010.01.016.

36. Crowe A, Huang W, Ballatore C, Johnson RL, Hogan A-ML, Huang R, et al. Identification of aminothienopyridazine inhibitors of tau assembly by quantitative high-throughput screening. Biochemistry. 2009;48:7732-45. https://doi.org/10.1021/bi9006435.

37. Taniguchi S, Suzuki N, Masuda M, Hisanaga S, Iwatsubo T, Goedert M, et al. Inhibition of heparin-induced tau filament formation by phenothiazines, polyphenols, and porphyrins. J Biol Chem. 2005;280:7614-23. https://doi.org/10.1074/jbc.M408714200.

38. Wischik CM, Harrington CR, Storey JMD. Tau-aggregation inhibitor therapy for Alzheimer's disease. Biochem Pharmacol. 2014;88:529-39. https://doi.org/10.1016/j.bcp.2013.12.008.

39. Jadhav S, Avila J, Schöll M, Kovacs GG, Kövari E, Skrabana R, et al. A walk through tau therapeutic strategies. Acta Neuropathol Commun. 2019;7:22. https://doi.org/10.1186/s40478-019-0664-z.

40. Schumacher TN, Mayr LM, Minor DL, Milhollen MA, Burgess MW, Kim PS. Identification of D-peptide ligands through mirror-image phage display. Science. 1996;271:1854-7. https://doi.org/10.1126/science.271.5257.1854.

41. Chalifour RJ, McLaughlin RW, Lavoie L, Morissette C, Tremblay N, Boulé $M$, et al. Stereoselective interactions of peptide inhibitors with the betaamyloid peptide. J Biol Chem. 2003;278:34874-81. https://doi.org/10. 1074/jbc.M212694200.

42. Sadowski M, Pankiewicz J, Scholtzova H, Ripellino JA, Li Y, Schmidt SD, et al. A synthetic peptide blocking the apolipoprotein E/ $\beta$-amyloid binding mitigates $\beta$-amyloid toxicity and fibril formation in vitro and reduces $\beta$-amyloid plaques in transgenic mice. Am J Pathol. 2004;165:937-48. https://doi.org/10.1016/S0002-9440(10)63355-X.

43. Funke SA, van Groen T, Kadish I, Bartnik D, Nagel-Steger L, Brener O, et al. Oral treatment with the d-enantiomeric peptide D3 improves the pathology and behavior of Alzheimer's disease transgenic mice. ACS Chem Neurosci. 2010;1:639-48. https://doi.org/10.1021/cn100057j.

44. Pappenheimer JR, Karnovsky ML, Maggio JE. Absorption and excretion of undegradable peptides: role of lipid solubility and net charge. J Pharmacol Exp Ther. 1997;280:292-300.

45. Leithold LHE, Jiang N, Post J, Ziehm T, Schartmann E, Kutzsche J, et al. Pharmacokinetic properties of a novel D-peptide developed to be therapeutically active against toxic $\beta$-amyloid oligomers. Pharm Res. 2016;33:328-36. https://doi.org/10.1007/s11095-015-1791-2.

46. Willbold D, Kutzsche J. Do We need anti-prion compounds to treat Alzheimer's disease? Molecules. 2019;24:2237. https://doi.org/10.3390/ molecules24122237.

47. Klein RM, Christie J, Parkvall M. Does multilingualism affect the incidence of Alzheimer's disease?: a worldwide analysis by country. SSM - Popul Health. 2016;2:463-7. https://doi.org/10.1016/j.ssmph.2016.06.002.

48. Kutzsche J, Schemmert S, Tusche M, Neddens J, Rabl R, Jürgens D, et al. Large-scale oral treatment study with the four most promising D3-derivatives for the treatment of Alzheimer's disease. Molecules. 2017. https://doi.org/10.3390/molecules22101693.

49. van Groen T, Wiesehan K, Funke SA, Kadish I, Nagel-Steger L, Willbold D. Reduction of Alzheimer's disease amyloid plaque load in transgenic mice by D3, A D-enantiomeric peptide identified by mirror image phage display. ChemMedChem. 2008;3:1848-52. https://doi.org/10.1002/cmdc. 200800273

50. Dammers C, Yolcu D, Kukuk L, Willbold D, Pickhardt M, Mandelkow E, et al. Selection and characterization of Tau binding $D_{D}$-enantiomeric peptides with potential for therapy of Alzheimer disease. PLoS One. 2016;11:e0167432. https://doi.org/10.1371/journal.pone.0167432.

51. Lo Cascio F, Garcia S, Montalbano M, Puangmalai N, McAllen S, Pace A, et al. Modulating disease-relevant tau oligomeric strains by small molecules. J Biol Chem. 2020:14807-25. https://doi.org/10.1074/jbc.RA120.014630.

52. Malhis M, Kaniyappan S, Aillaud I, Chandupatla RR, Ramirez LM, Zweckstetter $\mathrm{M}$, et al. Potent Tau aggregation inhibitor D-peptides selected against Tau-repeat 2 using mirror image phage display. ChemBioChem. 2021. https://doi.org/10.1002/cbic.202100287.

53. Margittai M, Langen R. Template-assisted filament growth by parallel stacking of tau. Proc Natl Acad Sci U S A. 2004;101:10278-83. https://doi. org/10.1073/pnas.0401911101.

54. Barghorn S, Biernat J, Mandelkow E. Purification of recombinant tau protein and preparation of Alzheimer-paired helical filaments in vitro. Methods Mol Biol. 2005;299:35-51.

55. Huang J, Ru B, Li S, Lin H, Guo F-B. SAROTUP: scanner and reporter of target-unrelated peptides. J Biomed Biotechnol. 2010;2010:101932. https://doi.org/10.1155/2010/101932.

56. Pettersen EF, Goddard TD, Huang CC, Couch GS, Greenblatt DM, Meng EC, Ferrin TE. UCSF Chimera--a visualization system for exploratory research and analysis. J Comput Chem 2004;25:1605-1612. doi:https://doi.org/10. 1002/jcc.20084. 
57. Humphrey W, Dalke A, Schulten K. VMD: visual molecular dynamics. J Mol Graph. 1996;14:33-8. https://doi.org/10.1016/0263-7855(96)00018-5.

58. Khlistunova I, Biernat J, Wang Y, Pickhardt M, von Bergen M, Gazova Z, et al. Inducible expression of Tau repeat domain in cell models of tauopathy: aggregation is toxic to cells but can be reversed by inhibitor drugs. J Biol Chem. 2006;281:1205-14. https://doi.org/10.1074/jbc.M507753200.

59. SantaCruz K, Lewis J, Spires T, Paulson J, Kotilinek L, Ingelsson M, et al. Tau suppression in a neurodegenerative mouse model improves memory function. Science. 2005;309:476-81. https://doi.org/10.1126/science. 1113694.

60. Eckermann K, Mocanu M-M, Khlistunova I, Biernat J, Nissen A, Hofmann $A$, et al. The beta-propensity of Tau determines aggregation and synaptic loss in inducible mouse models of tauopathy. J Biol Chem. 2007;282:31755-65. https://doi.org/10.1074/jbc.M705282200.

61. Decker JM, Krüger L, Sydow A, Zhao S, Frotscher M, Mandelkow E, et al. Pro-aggregant Tau impairs mossy fiber plasticity due to structural changes and $\mathrm{Ca}(++)$ dysregulation. Acta Neuropathol Commun. 2015;3:23. https://doi.org/10.1186/s40478-015-0193-3.

62. Hong M, Zhukareva V, Vogelsberg-Ragaglia V, Wszolek Z, Reed L, Miller BI, et al. Mutation-specific functional impairments in distinct tau isoforms of hereditary FTDP-17. Science. 1998;282:1914-7. https://doi.org/10.1126/ science.282.5395.1914.

63. Coppola G, Chinnathambi S, Lee JJ, Dombroski BA, Baker MC, SotoOrtolaza Al, et al. Evidence for a role of the rare p.A152T variant in MAPT in increasing the risk for FTD-spectrum and Alzheimer's diseases. Hum Mol Genet. 2012;21:3500-12. https://doi.org/10.1093/hmg/dds161.

64. Haas C. Strategies, development, and pitfalls of therapeutic options for Alzheimer's disease. J Alzheimers Dis. 2012;28:241-81. https://doi.org/10. 3233/JAD-2011-110986

65. Cummings J, Blennow K, Johnson K, Keeley M, Bateman RJ, Molinuevo $J$, et al. Anti-Tau trials for Alzheimer's disease: a report from the EU/US/ CTAD Task Force. J Prev Alzheimers Dis. 2019;6:157-63. https://doi.org/10. 14283/jpad.2019.14.

66. Lovestone S, Manji HK. Will we have a drug for Alzheimer's disease by 2030? The view from Pharma. Clin Pharmacol Ther. 2020;107:79-81. https://doi.org/10.1002/cpt.1685.

67. Hochgräfe K, Sydow A, Matenia D, Cadinu D, Könen S, Petrova O, et al. Preventive methylene blue treatment preserves cognition in mice expressing full-length pro-aggregant human Tau. Acta Neuropathol Commun. 2015;3:25. https://doi.org/10.1186/s40478-015-0204-4.

68. Chandupatla RR, Flatley A, Feederle R, Mandelkow E-M, Kaniyappan S. Novel antibody against low-n oligomers of tau protein promotes clearance of tau in cells via lysosomes. Alzheimers Dement (N Y). 2020;6:e12097. https://doi.org/10.1002/trc2.12097.

69. Ballatore C, Lee VM-Y, Trojanowski JQ. Tau-mediated neurodegeneration in Alzheimer's disease and related disorders. Nat Rev Neurosci. 2007;8:663-72. https://doi.org/10.1038/nrn2194.

70. Götz J, Di Xia LG, Chew YL, Nicholas H. What renders TAU toxic. Front Neurol. 2013;4:72. https://doi.org/10.3389/fneur.2013.00072.

71. Pir GJ, Choudhary B, Kaniyappan S, Chandupatla RR, Mandelkow E, Mandelkow E-M, et al. Suppressing tau aggregation and toxicity by an anti-aggregant Tau fragment. Mol Neurobiol. 2019;56:3751-67. https:// doi.org/10.1007/s12035-018-1326-Z.

72. Zhang $X$, Zhang $X$, Zhong M, Zhao P, Guo C, Li Y, et al. Selection of a d-enantiomeric peptide specifically binding to PHF6 for inhibiting Tau aggregation in transgenic mice. ACS Chem Neurosci. 2020;11:4240-53. https://doi.org/10.1021/acschemneuro.0c00518.

73. Pauling L, Corey RB. A proposed structure for the nucleic acids. Proc Natl Acad Sci. 1953;39:84-97. https://doi.org/10.1073/pnas.39.2.84.

74. Plumley JA, Ali-Torres J, Pohl G, Dannenberg JJ. Capping amyloid $\beta$-sheets of the tau-amyloid structure VQIVYK with hexapeptides designed to arrest growth. An ONIOM and density functional theory study. J Phys Chem B. 2014;118:3326-34. https://doi.org/10.1021/jp501890p.

75. Futaki S. Membrane-permeable arginine-rich peptides and the translocation mechanisms. Adv Drug Deliv Rev. 2005;57:547-58. https://doi.org/10. 1016/j.addr.2004.10.009.

76. Derossi D, Joliot AH, Chassaing G, Prochiantz A. The third helix of the Antennapedia homeodomain translocates through biological membranes. J Biol Chem. 1994;269:10444-50.
77. Gump JM, Dowdy SF. TAT transduction: the molecular mechanism and therapeutic prospects. Trends Mol Med. 2007;13:443-8. https://doi.org/ 10.1016/j.molmed.2007.08.002.

78. Frenkel-Pinter M, Richman M, Belostozky A, Abu-Mokh A, Gazit E, Rahimipour $\mathrm{S}$, et al. Selective inhibition of aggregation and toxicity of a tau-derived peptide using its glycosylated analogues. Chemistry. 2016;22:5945-52. https://doi.org/10.1002/chem.201504950.

79. Belostozky A, Richman M, Lisniansky E, Tovchygrechko A, Chill JH, Rahimipour S. Inhibition of tau-derived hexapeptide aggregation and toxicity by a self-assembled cyclic d,l-a-peptide conformational inhibitor. Chem Commun (Camb). 2018;54:5980-3. https://doi.org/10.1039/c8cc01233d.

80. Zheng J, Liu C, Sawaya MR, Vadla B, Khan S, Woods RJ, et al. Macrocyclic $\beta$-sheet peptides that inhibit the aggregation of a tau-protein-derived hexapeptide. J Am Chem Soc. 2011;133:3144-57. https://doi.org/10. 1021/ja110545h.

81. Pickhardt M, Biernat J, Hübschmann S, Dennissen FJA, Timm T, Aho A, et al. Time course of Tau toxicity and pharmacologic prevention in a cell model of Tauopathy. Neurobiol Aging. 2017;57:47-63. https://doi.org/10. 1016/j.neurobiolaging.2017.04.022.

82. Pickhardt M, Tassoni M, Denner P, Kurkowsky B, Kitanovic A, Möhl C, et al. Screening of a neuronal cell model of tau pathology for therapeutic compounds. Neurobiol Aging. 2018;76:24-34. https://doi.org/10.1016/j. neurobiolaging.2018.11.026.

\section{Publisher's Note}

Springer Nature remains neutral with regard to jurisdictional claims in published maps and institutional affiliations.
Ready to submit your research? Choose BMC and benefit from:

- fast, convenient online submission

- thorough peer review by experienced researchers in your field

- rapid publication on acceptance

- support for research data, including large and complex data types

- gold Open Access which fosters wider collaboration and increased citations

- maximum visibility for your research: over $100 \mathrm{M}$ website views per year

At BMC, research is always in progress.

Learn more biomedcentral.com/submissions 